\title{
Previous military experience and entrepreneurship toward poverty reduction: evidence from China
}

\author{
Zuhui Xu \\ Business School \\ Nanjing University of Finance and Economics \\ 128 Railway N St, Gulou, Nanjing, Jiangsu, China \\ xuzuhui1990@163.com; \\ Bin Li \\ Business School \\ Shanghai University of Finance and Economics \\ Room 511, No.100 Wudong Road \\ Shanghai, China \\ Email: binli1003@163.com; \\ Zhiyang Liu \\ Business School \\ Shanghai University of Finance and Economics \\ Room 511, No.100 Wudong Road \\ Shanghai, China \\ Email: zhiyang163@163.com
}

\author{
$\mathrm{Wu}, \mathrm{Jie}$ \\ Business School \\ University of Aberdeen \\ Aberdeen, AB24 3FX, UK \\ Email: jiewu@abdn.ac.uk
}


Previous military experience and entrepreneurship toward poverty reduction: evidence from China

\begin{tabular}{|r|l|}
\hline Journal: & Management Decision \\
\hline Manuscript ID & MD-01-2021-0160.R2 \\
\hline Manuscript Type: & Original Article \\
\hline Keywords: & Entrepreneurship, Small enterprises \\
\hline \multicolumn{2}{|l}{} \\
\end{tabular}

SCHOLARONE $^{\text {m }}$
Manuscripts 


\section{ABSTRACT:}

Research on entrepreneurship toward poverty reduction has outlined how micro-level characteristics of entrepreneurs capture entrepreneurial opportunities in settings of poverty; however, little is known about the influence of previous military experience in this context. This paper investigates how previous military experience influences poverty-reduction entrepreneurship.

This study uses data from two main sources. First, individual-level and firm-level information comes from a nationwide survey of founders of private enterprises. Second, province-level information is taken from the Marketization Index and the China Statistics Yearbook. An analysis of the Logit moderation model renders strong support for our conjectures.

Via novel integration of imprinting theory and research on previous military experience, we propose that entrepreneurs with previous military experience have a strong sense of self-sacrifice and, as a result, are better able to participate in poverty-reduction entrepreneurship. In addition, we build on the resource availability and stakeholder expectations arguments and predict that the main effect of previous military experience on poverty-reduction entrepreneurship will be strengthened by reduced corporate philanthropy and increased government intervention.

CUST_RESEARCH_LIMITATIONS/IMPLICATIONS_(LIMIT_100_WORDS) :No data available.

CUST_PRACTICAL_IMPLICATIONS_(LIMIT_100_WORDS) :No data available.

CUST_SOCIAL_IMPLICATIONS_(LIMIT_100_WORDS) :No data available.

Our study adds to the extant literature in the following ways. First, it enriches the literature on entrepreneurship toward poverty reduction. Second, it contributes to imprinting theory in the entrepreneurial field. Third, it adds knowledge to the social entrepreneurship literature. 


\title{
Previous military experience and entrepreneurship toward poverty reduction: evidence from China
}

\begin{abstract}
Purpose - Research on entrepreneurship toward poverty reduction has outlined how micro-level characteristics of entrepreneurs capture entrepreneurial opportunities in settings of poverty; however, little is known about the influence of previous military experience in this context. This paper investigates how previous military experience influences poverty-reduction entrepreneurship.
\end{abstract}

Design/methodology/approach - This study uses data from two main sources. First, individual-level and firm-level information comes from a nationwide survey of founders of private enterprises. Second, province-level information is taken from the Marketization Index and the China Statistics Yearbook. An analysis of the Logit moderation model renders strong support for our conjectures.

Findings - Via novel integration of imprinting theory and research on previous military experience, we propose that entrepreneurs with previous military experience have a strong sense of self-sacrifice and, as a result, are better able to participate in povertyreduction entrepreneurship. In addition, we build on the resource availability and stakeholder expectations arguments and predict that the main effect of previous military experience on poverty-reduction entrepreneurship will be strengthened by reduced corporate philanthropy and increased government intervention.

Originality/value - Our study adds to the extant literature in the following ways. First, it enriches the literature on entrepreneurship toward poverty reduction. Second, it 
contributes to imprinting theory in the entrepreneurial field. Third, it adds knowledge to the social entrepreneurship literature.

Keywords - Previous military experience, poverty-reduction entrepreneurship, corporate philanthropy, government intervention, imprinting theory, Chinese context

Paper type - Research paper

\section{Introduction}

Poverty-reduction entrepreneurship is defined as addressing social problems, such as poverty and discrimination, through market-based methods (Bruton et al., 2013; Kimmitt et al., 2020; Sutter et al., 2019). There has been increasing effort in the field of entrepreneurship toward poverty reduction to explore the important role of individual-level factors in entrepreneurial behaviors and outcomes. This stream resonates well with certain theories, such as human capital theory (Estrin et al., 2016) and the attention-based view (Stevens et al., 2015), as key frameworks to explain the relationship between individual-level factors and entrepreneurial activities and outcomes. Several individual-level factors have been investigated in this stream of research, alongside demographic characteristics and personality traits. Specifically, demographic characteristics include age (Hörisch et al., 2017), human capital (Estrin et al., 2016), gender (Fletschner and Mesbah, 2011; Lortie et al., 2017), religion (Katre and Salipante, 2012) and prior experience with social problems (Hockerts, 2017), while personality traits cover CEO values (Stevens et al., 2015), the Big Five (Nga and 
Shamuganathan, 2010), moral sentiments (Smith et al., 2016; Yiu et al., 2014), prosocial motivation (Miller et al., 2012; Renko, 2013), an orientation toward the future (Bruton et al., 2011) and intrinsic motivation (Randøy et al., 2015).

However, little is known within the field of entrepreneurship toward poverty reduction about the influence of previous military experience. Military experience emphasizes service to the people and may thus instill a strong sense of self-sacrifice (Koch-Bayram and Wernicke, 2018). Some recent literature examined how previous military experience influences entrepreneurs' decision making, including corporate fraudulent activity (Benmelech and Frydman, 2015), tax avoidance (Law and Mills, 2017), financial misconduct (Koch-Bayram and Wernicke, 2018) and environmental protection (Gao et al., 2021). Although research has examined the effects of military experience on strategic decision making, an entrepreneur's previous military experience as an important component of individual characteristics has not been adequately studied in the entrepreneurial context.

Grounded in the research on military experience and imprinting theory, we postulate that previous military experience can imprint a strong sense of self-sacrifice, and that it helps entrepreneurs adopt other-regarding values, thereby facilitating their participation in poverty-reduction entrepreneurship. Furthermore, based on the resource availability and stakeholder expectations arguments, we predict that such a relationship will be strengthened when the influence of previous military experience is subject to reduced corporate philanthropy and increased government expectations.

Our study contributes to the literature in the following ways. First, it contributes to 
existing literature on the antecedents of poverty-reduction entrepreneurship. This study joins a growing body of literature that emphasizes the role of demographic characteristics and personality traits in entrepreneurial intentions and behaviors toward poverty reduction (Nga and Shamuganathan, 2010; Stevens et al., 2015; Sutter et al., 2019). Second, it examines the applicability of imprinting theory in explaining entrepreneurial behaviors. This study indicates that entrepreneurs' imprinting characteristics, such as previous military experience during a period of susceptibility, have a long-lasting impact on their entrepreneurial behaviors toward poverty reduction (Marquis and Tilcsik, 2013; Marquis and Qiao, 2020). Third, it documents contingent roles of resource availability and stakeholder expectations in the relationship between entrepreneurs' previous military experience and social entrepreneurship. This study suggests that the effects of imprinted characteristics on social entrepreneurship may depend on a reduction in corporate philanthropy and increase in government expectations.

\section{Theory and hypotheses}

\section{Imprinting theory and military experience in China}

Imprinting theory emphasizes two general characteristics: the existence of a sensitive period and the subsequent stability of the result of experience gained during that period (Marquis and Tilcsik, 2013). Most individuals join the military after they turn 18-a sensitive period when they are susceptible to the influence of military values. These military values, such as service to the people and self-sacrifice, have a lasting impact 
on subsequent decision making (Marquis and Lee, 2013). This is because military experience, during the individuals' early-career stage, significantly shapes individuals' moral values and behaviors (Elder, 1986; Elder et al., 1991). It has also been indicated that previous military experience can influence entrepreneurs' strategic behaviors and outcomes (Benmelech and Frydman, 2015; Gao et al., 2021; Koch-Bayram and Wernicke, 2018; Law and Mills, 2017; Luo et al., 2017). For example, Koch-Bayram and Wernicke (2018) found that CEOs with a military background are less likely to be involved in fraudulent financial reporting or to backdate stock options. This exploration has recently been extended into corporate social responsibility in the context of China. For instance, Gao et al. (2021) found that military service experience may instill in CEOs pro-environmental values such as duty, self-discipline, self-sacrifice and a sense of community, and motivate them to invest more resources in environmental protection.

Military experience is given prevalence in both Eastern and Western contexts, and shapes the characteristics of military personnel in several ways. On the Eastern side, the Chinese army has its own discipline and beliefs. The idea of service to the people stresses that the Chinese army must serve the people through loyalty and integrity, which imprints on Chinese soldiers a strong sense of discipline, self-sacrifice, loyalty and community, such as investing more resources in environmental protection (Gao et al., 2021), protecting the country and helping poverty-stricken groups (Cao et al., 2019). On the Western side, military experience imprints a strong sense of integrity, dedication and self-sacrifice. For example, the military may inculcate a value system that includes loyalty, integrity, service and sacrifice in the interests of others that encourages CEOs 
to make ethical decisions, such as a reduced likelihood of involvement in corporate fraudulent activity (Benmelech and Frydman, 2015), tax avoidance (Law and Mills, 2017) or fraudulent financial reporting (Koch-Bayram and Wernicke, 2018).

In brief, Eastern and Western research regarding the importance of previous military experience has focused on strategic decision making based on value systems such as service to the people and self-sacrifice; however, the findings on previous military experience have not extended into entrepreneurial contexts such as poverty-reduction entrepreneurship and how this is affected by the imprinting influence of military service (Marquis and Tilcsik, 2013; Marquis and Qiao, 2020).

\section{Poverty-reduction entrepreneurship in Chinese private entrepreneurs}

Poverty-reduction entrepreneurship involves addressing social problems, such as poverty and discrimination, through market-based methods (Bruton et al., 2013; Kimmitt et al., 2020; Sutter et al., 2019). Poverty-reduction entrepreneurship can simultaneously balance the relationship between social and economic value, in contrast to commercial entrepreneurship, which is driven by economic value only (Bruton et al., 2013). Furthermore, poverty-reduction entrepreneurship involves several key entrepreneurial behaviors, such as identifying and exploiting opportunities and the innovation process (Sutter et al., 2019).

There are three primary underlying perspectives on entrepreneurial activities toward poverty reduction: remediation, reform and revolution (Sutter et al., 2019). The remediation perspective assumes that poverty is alleviated by providing greater access 
to resources. Some studies have explored individuals' entrepreneurial actions, such as partnerships and increasing human capital through training, to overcome resource scarcity (Ahlin and Jiang, 2008; Sutter et al., 2014). The reform perspective considers poverty as a result of social exclusion. Some entrepreneurial actions can dramatically reshape the institutional or social context, which facilitates inclusion (George et al., 2012; Mair et al., 2012). The revolution perspective indicates that poverty is the result of corrupt and broken systems. Some entrepreneurial actions can be taken as changing the underlying capitalist-based assumptions of business (Peredo and Chrisman, 2006; Singer, 2006) and introducing alternative economic systems for a more equal society (Rindova et al., 2009; Shakya and Rankin, 2008).

The phenomenon of poverty-reduction entrepreneurship is still emerging in China (Bhatt et al., 2019), and entails a variety of organizing forms, such as rural cooperatives (Lan et al., 2014), rural enterprises (Poon et al., 2009), for-profit entrepreneurs participating in the Guangcai/Glorious Program, a nongovernmental, social program that reduces poverty through entrepreneurial activities (Yiu et al., 2014) and nonprofit entrepreneurs (Yu, 2013). For example, according to an analysis from a 2006 nationwide survey of Chinese entrepreneurs, some commercial entrepreneurs have participated in poverty-reduction entrepreneurial activities equipped with advanced technology to turn poverty issues into business opportunities (Yiu et al., 2014).

The influence of previous military experience on poverty-reduction entrepreneurship (hypothesis 1) 
Past studies have indicated that previous military experience may play an important role in entrepreneurs' strategic behaviors and outcomes (Benmelech and Frydman, 2015; Gao et al., 2021; Koch-Bayram and Wernicke, 2018; Law and Mills, 2017; Luo et al., 2017). Robust evidence has demonstrated that entrepreneurs' previous military experience imprints a strong sense of duty, honor, integrity, selflessness and selfdiscipline (Gao et al., 2021), such that they are comparatively more likely to obey rules and regulations (Koch-Bayram and Wernicke, 2018). However, extant research has neglected to extend the influence of previous military experience into a specific entrepreneurial context, such as poverty-reduction entrepreneurship. Some studies have suggested that the Chinese army imprints on Chinese soldiers a strong sense of discipline, self-sacrifice, loyalty and community, such as investing more resources in environmental protection (Gao et al., 2021). Compared with environmental protection, poverty-reduction entrepreneurship has several specific characteristics, such as involving key entrepreneurial behaviors including identifying and exploiting opportunities and the innovation process (Sutter et al., 2019). This implies that the internal mechanisms between previous military experience and poverty-reduction entrepreneurship may differ. Thus, we posit that previous military experience can promote commercial entrepreneurs to engage in poverty-reduction entrepreneurship because of the unique imprinting derived from that experience, including a sense of service to the people and self-sacrifice.

Previous military experience imprints sense of ethics on entrepreneurs, while adopting other-regarding values is a necessary condition of entrepreneurship toward 
poverty reduction. As a unique concept, the idea of service to the people emphasizes that the Chinese army must serve the people with all their heart, and teaches soldiers to protect the country and help poverty-stricken groups (Luo et al., 2017). Entrepreneurs with previous military experience are more likely to be imprinted by key military values, such as self-sacrifice and a sense of community, in contrast to entrepreneurs without previous military experience. For example, they often take advantage of opportunities and programs to address poverty issues. Some studies (Mair and Noboa, 2006; Stevens et al., 2015) have indicated theoretically and empirically that other-regarding values are an important factor driving the relative attention to social issues such as poverty and discrimination. Thus, the current study proposes that entrepreneurs with previous military experience imprint values inherent in the military, such as service to the people and self-sacrifice, which triggers their adoption of other-regarding values and thereby stimulates them to engage in poverty-reduction entrepreneurship.

In summary, entrepreneurs with previous military experience are imprinted by aspects of the military relating to values, such as service to the people in the Chinese context, in contrast to those without previous military experience, thereby encouraging the former group to engage in establishing entrepreneurial firms in less-developed regions. Therefore, we hypothesize the following:

H1. Commercial entrepreneurs' previous military experience is positively related to their engagement in entrepreneurship toward poverty reduction.

The moderating effect of corporate philanthropy (hypothesis 2) 
Compared to commercial entrepreneurship, the values of previous military experience can promote entrepreneurs' engagement in poverty-reduction entrepreneurship through service to the people and self-sacrifice. We further examine a boundary condition of the relationship between an entrepreneur's previous military experience and their entrepreneurship toward poverty reduction. We draw on the resource availability argument, which comes from the human, physical, technological and financial capital available to the commercial entrepreneur (Stevens et al., 2015). Entrepreneurship toward poverty reduction influenced by the values of previous military experience encourages the commercial entrepreneur to invest time and resources in less-developed regions ( $\mathrm{Wu}$ and $\mathrm{Si}, 2018)$. However, how previous military experience is transformed into poverty-reduction entrepreneurship is dependent on commercial entrepreneurs' resource availability.

Corporate philanthropy involves attitudes and behaviors regarding gifts or monetary contributions toward social and charitable causes (Mazereeuw-van der Duijn Schouten et al., 2014; Wang and Qian, 2011). The existing literature has shown that corporate philanthropy includes diverse motivations, such as strategic motivation, political motivation, managerial self-interest motivation and altruistic motivation, and absorbs entrepreneurs' time and resources (Aguinis and Glavas, 2012; Du, 2017). For example, Wang and Qian (2011) proposed that corporate philanthropy involves firms donating resources such as gifts or money to social and charitable causes. Moreover, Luo et al. (2017) demonstrated that firms' charitable giving may involve them committing money and resources to disaster areas, such as in the case of the 2008 Sichuan earthquake. 
Building on these resource availability arguments, we propose that corporate philanthropy absorbs ex-military entrepreneurs' available time and resources, reducing their ability to invest time and resources in the process of entrepreneurship toward poverty reduction. When commercial entrepreneurs without engagement in corporate philanthropy leave abundant time and resources availability, they will be more likely to allocate limited time and resources to social goals, strengthen their other-regarding values imprinted by previous military experience, and engage in more entrepreneurship toward poverty reduction. As commercial entrepreneurs make more donations, these charitable behaviors absorb their limited time and resources, and force them to improve existing time and resource allocation efficiency rather than to make new investments in less-developed regions. For example, corporate philanthropy not only fulfills moral obligations but also increases political legitimacy and captures entrepreneurial opportunities such as establishing businesses in less-developed regions (Liu et al., 2019; Wang and Qian, 2011). Therefore, we predict the following:

\author{
H2. Corporate philanthropy weakens the positive relationship between commercial \\ entrepreneurs ' previous military experience and their entrepreneurship toward \\ poverty reduction.
}

The moderating effect of government intervention (hypothesis 3)

The stakeholder expectations perspective identifies the government as an important stakeholder (Donaldson and Preston, 1995) and is based on a concern with moral obligations (Aguilera et al., 2007; Aguinis and Glavas, 2012). Government intervention 
refers to the regulation of individual or organizational activities using a command-andcontrol framework based on a bureaucratic hierarchy (Zhao and Lu, 2016). In China, government agencies have high expectations with respect to commercial entrepreneurs' commitment to other-regarding behaviors, and persuade them to engage in entrepreneurship toward poverty reduction to fulfill moral obligations $(\mathrm{Wu}$ and $\mathrm{Si}$, 2018). In markets where business activities are subject to greater government intervention, the local government's expectations with regard to moral obligations will be higher (Bruton et al., 2010). In regions with greater government intervention, key stakeholders such as government agencies are regarded as a source of social pressure, retaining normative expectations and highlighting the pursuit of moral obligations, which strengthens commercial entrepreneurs' other-regarding values imprinted by previous military experience and encourages them to engage in more entrepreneurship toward poverty reduction. Thus, commercial entrepreneurs located in regions with more government intervention are more likely to be influenced by the extent to which government officials provide social expectations regarding moral obligations, and the influence of previous military experience on entrepreneurship toward poverty reduction may be strengthened. In contrast, in a context of narrow government intervention, market fundamentals, rather than government departments, play more important roles in social expectations and regulations; entrepreneurs may not depend to such a high degree on government expectations about moral obligations. In this situation, commercial entrepreneurs with previous military experience may not need to participate in entrepreneurship toward poverty reduction to meet government 
expectations. Accordingly, we predict the following:

H3. Government intervention strengthens the positive relationship between commercial entrepreneurs' previous military experience and entrepreneurship toward poverty reduction.

\section{Research model}

In the theoretical model (Figure 1), previous military experience imprints the values of the military, which influences entrepreneurs' engagement in poverty-reduction entrepreneurship. Furthermore, the values of the military can encourage them to participate in poverty-reduction entrepreneurship through service to the people and selfsacrifice, and the main effect of previous military experience on poverty-reduction entrepreneurship is dependent on corporate philanthropy and government intervention, respectively.

----Insert Figure 1 about here----

\section{Method}

Data

Data were obtained from the following sources. First, entrepreneur-level characteristics such as poverty-reduction entrepreneurship, previous military experience and corporate philanthropy were obtained from a 2006 nationwide survey of founders of private enterprises. The survey was conducted jointly by the United Front Work Department of the Party Central Committee, the All-China Federation of Industry and Commerce, the State Administration for Industry and Commerce of China and the Private Economy 
Research Institute of China. Similar data have been used in the social entrepreneurship field (e.g., Yiu et al., 2014). Second, the 2006 nationwide survey provided firm-level information, such as firm age, firm size and R\&D intensity. Third, data were collected on province-level government intervention and law enforcement from the 2006 Marketization Index and province-level GDP growth from the 2006 China Statistics Yearbook (Fan et al., 2011; Yiu et al., 2014).

We constructed our sample as follows. First, we excluded 101 observations for which information on previous military experience, poverty-reduction entrepreneurship and corporate philanthropy was missing. Second, we removed 50 observations with missing information on individual-level control variables. Finally, we eliminated 625 observations with missing information on firm-level and province-level control variables. For each of the above procedures involving the removal of missing data, we conducted unpaired t-tests and found no significant differences in previous military experience or poverty-reduction entrepreneurship between sample firms and those that we excluded. Our final sample contains 3,061 private enterprises.

\section{Measures}

Dependent variables. In China, poverty-reduction entrepreneurship has a variety of organizational forms, such as rural cooperatives, rural enterprises and for-profit entrepreneurs (Bhatt et al., 2019). In line with previous literature (e.g., Yiu et al., 2014), this study uses two primary indicators to measure the dependent variable of povertyreduction entrepreneurship, defined as commercial entrepreneurs' engagement in 
entrepreneurial activities for reducing poverty; these indicators were taken from a 2006 national survey of founders of private enterprises. Commercial entrepreneurs' engagement in poverty-reduction entrepreneurship 1 (PE1) is a dummy variable that takes the value of 1 if an entrepreneur has participated in establishing entrepreneurial firms in less-developed regions (with the aim not only of capturing uncertain entrepreneurial opportunities but also of developing new agricultural products to enhance local employment and reduce poverty) and 0 otherwise. Commercial entrepreneurs' engagement in poverty-reduction entrepreneurship 2 (PE2) is used for the robustness test and measured using an alternative count measure of PE1.

Independent variables. Following Hechavarria's (2016) consideration that values change very slowly, the stability of previous military experience among different waves of nationwide surveys is confirmed by a strong similar percentage (Gao et al., 2021). Previous military experience is a dummy variable, which equals 1 if the entrepreneur has military experience and 0 otherwise.

Moderating variables. Following the extant literature (e.g., Mazereeuw-van der Duijn Schouten et al., 2014), corporate philanthropy 1 (CP1) is measured by entrepreneurs' attitudes toward philanthropy; responses are based on a 5-point Likert scale ranging from $1=$ "strong unimportance" to $5=$ "strong importance." According to the previous literature (e.g., Zhao and $\mathrm{Lu}, 2016$ ), government intervention is measured by the level of government involvement in firms' activities from Fan et al.'s (2011) Marketization Index. Higher numbers indicate a lower level of government intervention. 
Control variables. This study uses several individual-level, firm-level and provincelevel control variables. The individual-level variables include gender, level of education, political connections, unemployment experience, rural poverty experience and startup location hardship. Gender is a dummy variable, equaling 1 if the entrepreneur of the private enterprise is female and 0 otherwise. Level of education is measured from $1=$ primary school to $6=$ postgraduate. Political connections is a dummy variable equaling 1 if the entrepreneur is a deputy of the People's Congress (PC) and/or the Chinese People's Political Consultative Committee (CPPCC) and 0 otherwise. Unemployment experience is a dummy variable that equals 1 if the entrepreneur has experienced past unemployment and 0 otherwise. Rural poverty experience is a dummy variable equaling 1 if the entrepreneur has prior working experience in a village committee and 0 otherwise. Startup location hardship is a dummy variable equaling 1 if startups of the private enterprise are located in small cities, towns or villages and 0 otherwise. Firmlevel variables comprise firm age, firm size, research and development (R\&D) intensity and performance. Firm age is calculated by subtracting from 2006 the year in which the firm registered as a private enterprise. Firm size is measured as the natural logarithm of paid-in capital during the establishment of a private enterprise. $R \& D$ intensity is measured by the R\&D expenditure in 2005 divided by paid-in capital. Performance indicates a return on assets and is measured by the net profit in 2005 divided by paidin capital. Province-level variables mainly refer to law enforcement and gross domestic product (GDP) growth. Law enforcement is measured by the development of intermediary agencies and legal enforcement from Fan et al.'s (2011) Marketization 
Index. GDP growth is measured by the 2006 GDP Index compared to 2005 and is taken from the 2006 China Statistics Yearbook.

\section{Analytical approach}

To account for the limit of commercial entrepreneurs engaging in poverty-reduction entrepreneurship, this study tests the theoretical model shown in Figure 1 using a Logit model for empirical analysis. In addition, this study uses interaction terms to test the moderating effect of corporate philanthropy and government intervention. The procedure is as follows. First, we test the positive relationship between entrepreneurs with previous military experience and poverty-reduction entrepreneurship (H1). Second, we examine the moderating role of corporate philanthropy between the twos (H2). Third, we verify the moderating role of government intervention between the twos (H3). This study also uses simple slope analysis and interaction plots to examine the significance of the moderating effects.

\section{Results}

Table I reports the descriptive statistics and Pearson correlations between the key variables. As shown in Table I, the mean value of PE1, the dependent variable, is 0.123 , revealing that about $12.3 \%$ of entrepreneurs in Chinese private enterprises have participated in establishing entrepreneurial firms in less-developed regions with the aim not only of capturing uncertain entrepreneurial opportunities but also of developing new agricultural products to enhance local employment and reduce poverty. Moreover, 
the mean value of previous military experience, the main independent variable, is 0.047 , revealing that about $4.7 \%$ of entrepreneurs in Chinese private enterprises have previous military experience, which is consistent with 2008, 2010 and 2012 nation-wide surveys that military experience accounted for about 3.12\% of private entrepreneurs (Gao et al., 2021). The mean value of corporate philanthropy 1 is 3.207 , meaning that corporate philanthropy falls within the central tendency. The standard deviation of government intervention is 2.746 , indicating that government intervention varies widely across different regions.

Table I also shows the Pearson correlations for the variables used in this study. The results in Table I reveal that previous military experience is significantly positively correlated with PE1 and PE2 $(0.030$ with $p$ value $<0.05$ and 0.038 with $p$ value $<0.05$, respectively), suggesting that entrepreneurs with previous military experience are more likely to participate in poverty-reduction entrepreneurship. This result preliminarily supports Hypothesis 1. Moreover, the coefficients of pairwise correlations among the control variables are generally low, and the average variance inflation factor (VIF) is less than 3, suggesting that there is no serious multicollinearity. ----Insert Table I about here----

Table II presents the results of testing Hypotheses 1, 2 and 3. In Table II, Model 1 includes individual-level, firm-level and province-level control variables. Model 2 adds the main effect of one focal predictor and shows that previous military experience is positively and significantly related to commercial entrepreneurs' poverty-reduction entrepreneurship $(\beta=0.483, p<0.05)$. Thus, Hypothesis 1 is supported. Model 3 adds 
the interaction term of previous military experience and corporate philanthropy, and the coefficient is negative and significant $(\beta=-0.636, p<0.01)$. Model 4 adds the interaction term of previous military experience and government intervention, and the coefficient is negative and significant $(\beta=-0.144, p<0.05)$. The simple slope analyses reveal that the positive relationship between previous military experience and povertyreduction entrepreneurship is stronger for less corporate philanthropy and more government intervention $\left(\beta_{\text {corporate philanthropy }}=0.936, p<0.01 ; \beta_{\text {government intervention }}=0.878\right.$, $p<0.05)$ than for entrepreneurs with more corporate philanthropy and less government intervention $(\beta=0.030$, n.s.; $\beta=0.088$, n.s.). We illustrate this moderating effect in Figures 2 and 3; they show that entrepreneurs with previous military experience who enact more corporate philanthropy and experience less government intervention are less likely to participate in poverty-reduction entrepreneurship. These results provide joint support for Hypotheses 2 and 3.

----Insert Table II and Figures 2 and 3 about here----

\section{Robustness checks}

To ensure our results are robust, we conducted multiple robustness checks. First, we reran the empirical analysis using a Probit model. As shown in Model 2 of Table III, previous military experience is positively and significantly related to commercial entrepreneurs' poverty-reduction entrepreneurship. Thus, Hypothesis 1 is again supported. In Models 3 and 4 of Table III, the coefficients are negative and significant. The simple slope analyses and interaction plots in Figures 4 and 5 also support the moderating effect of corporate philanthropy and government intervention. Thus, Hypotheses 1, 2 and 3 are once again confirmed. 
----Insert Table III and Figures 4 and 5 about here----

Second, we reran the analyses with alternative measures of the dependent variables. Apart from the establishment of entrepreneurial firms in less-developed regions, with the aim not only of capturing uncertain entrepreneurial opportunities but also of developing new agricultural products to enhance local employment and reduce poverty for poverty-reduction entrepreneurship, an alternative count measure of an entrepreneur's participation in poverty-reduction entrepreneurship can also indicate their poverty-reduction entrepreneurship. As shown in Table IV and Figures 6 and 7, this alternative measure of poverty-reduction entrepreneurship generates consistent results. Thus, Hypotheses 1, 2 and 3 are once again supported.

----Insert Table IV and Figures 6 and 7 about here----

Third, we reran the analyses with alternative measures of the moderating variable of corporate philanthropy. Apart from corporate philanthropy 1 (CP1), which is measured by entrepreneurs' attitudes toward philanthropy, corporate philanthropy 2 (CP2) is also indicated by the natural logarithm of the amount of a commercial entrepreneur's charitable donations. As shown in Table $\mathrm{V}$ and Figure 8, this alternative measure of corporate philanthropy generates consistent results. Thus, Hypothesis 2 is once again supported.

----Insert Table V and Figure 8 about here----

Fourth, there was a potential endogeneity issue regarding the relationship between previous military experience and poverty-reduction entrepreneurship, largely due to unobservable factors. To eliminate this issue, we adopted the two-stage least squares (2SLS) approach. We used military culture as an instrumental variable. Military culture 
is measured by the number of soldiers killed in the War to Resist US Aggression and Aid Korea (WRUAAK) per capita in a province. WRUAAK in a province is expected to be highly correlated with entrepreneurs' previous military experience but should be uncorrelated with the error term (Cao et al., 2019).

Table VI presents the results of testing Hypothesis 1. In the second stage of the 2SLS regression (Model 2), previous military experience is positively and significantly related to entrepreneurs' poverty-reduction entrepreneurship. Thus, Hypothesis 1 is supported.

\section{----Insert Table VI about here----}

Fifth, we examine imprinting mechanisms such as other-regarding values between previous military experience and poverty-reduction entrepreneurship. Some studies have indicated that entrepreneurs with other-regarding values often work for the welfare of others, such as hiring workers from less-developed areas (Stevens et al., 2015; Cao et al., 2019). We use the number of employees from less-developed areas to indicate entrepreneurs' other-regarding values. Our results in Table VII suggest that previous military experience is indeed positively related to the number of employees from lessdeveloped areas and express the greater other-regarding values among those with military experience.

\section{----Insert Table VII about here----}

Lastly, we rule out political connections as the alternative mechanism between previous military experience and poverty-reduction entrepreneurship. On the one hand, as shown in all tables in this study, we control for entrepreneurs' political connections and find that the coefficient on military experience is still significantly positive. On the 
other hand, we also empirically examine how previous military experience influences their political motivations. Political motivation means entrepreneurs have strong desire to be involved in the PC or the CPPCC (Wang and Qian, 2011). Our results in Table VIII suggest that previous military experience is indeed negatively related to political motivation, and have less desire to be involved in the PC or the CPPCC. In addition, we empirically examine how corporate philanthropy influences political motivation. The results in Table VIII indicate that corporate philanthropy is indeed positively related to political motivation, and have more desire to be involved in the PC or the CPPCC.

\section{----Insert Table VIII about here----}

\section{Conclusion and implications}

This empirical study enhances understanding of how previous military experience facilitates commercial entrepreneurs' engagement in poverty-reduction entrepreneurship. Analysis of a nationwide survey of 3,061 Chinese entrepreneurs confirms that entrepreneurs with previous military experience tend to participate in poverty-reduction entrepreneurship; the positive influence of entrepreneurs' previous military experience on poverty-reduction entrepreneurship strengthens when the entrepreneurs are faced with reduced corporate philanthropy and increased government intervention.

\section{Theoretical implications}

First, this study contributes to the poverty-reduction entrepreneurship literature by 
demonstrating that previous military experience, which imprints values related to selfsacrifice, can facilitate commercial entrepreneurs' engagement in poverty-reduction entrepreneurship. Past literature has mainly focused on the influences of demographic characteristics and personality traits on entrepreneurial intentions and behaviors (Nga and Shamuganathan, 2010; Stevens et al., 2015), providing little evidence regarding the influence of demographic characteristics, such as previous military experience, on poverty-reduction entrepreneurship (Sutter et al., 2019).

Second, this study contributes to imprinting theory in the entrepreneurship field by highlighting a long-lasting mechanism between entrepreneurs' previous military experience and poverty-reduction entrepreneurship. Similar research regarding the importance of previous military experience has been conducted on investment in environmental protection (Gao et al., 2021), but the findings have neglected the effect of previous military experience on poverty-reduction entrepreneurship due to imprinting influence (Marquis and Tilcsik, 2013; Marquis and Qiao, 2020). Our study indicates that the imprinting influence of previous military experience, such as a strong sense of self-sacrifice, can adopt other-regarding values for participating in povertyreduction entrepreneurship.

Third, this study enriches the social entrepreneurship literature by highlighting the boundary condition between entrepreneurs' previous military experience and povertyreduction entrepreneurship. Recent literature has indicated that poverty-reduction entrepreneurship is one organizational form of social entrepreneurship in the Chinese context (Yiu et al., 2014), while ignoring the influence of resource availability and 
stakeholder expectations between previous military experience and social entrepreneurship (Wu et al., 2020).

\section{Managerial implications}

In addition to theoretical contributions, this study has several practical implications for entrepreneurial firms, entrepreneurs and government agencies. First, if an entrepreneurial firm wants to capture entrepreneurial opportunities in less-developed regions to meet moral obligations, having a CEO with previous military experience is an advantage. Second, this study advocates for entrepreneurial firms and their entrepreneurs to pay more attention to the balance of economic goals and social goals for entrepreneurship toward poverty reduction. Third, government officials in China need to improve the legitimacy of social entrepreneurship and provide more supportive rules and regulations for their survival and development.

\section{Limitations and future research}

This study is subject to certain limitations, which provide directions for future research. First, we only consider whether commercial entrepreneurs engage in poverty-reduction entrepreneurship. Future research may use other data to explore the relationship between previous military experience and other forms of social entrepreneurship. Second, this study does not differentiate between different types of previous military experience. Future studies should investigate the influences of different types of previous military experience on poverty-reduction entrepreneurship using the latest 
survey data. Third, future research should explore similar resource availability and stakeholder expectations between previous military experience and poverty-reduction entrepreneurship under other country contexts to generalize our findings.

\section{References}

Aguilera, R. V., Rupp, D. E., Williams, C. A. and Ganapathi, J. (2007), "Putting the S back in corporate social responsibility: a multilevel theory of social change in organizations", Academy of Management Review, Vol. 32 No. 3, pp. 836-863.

Aguinis, H. and Glavas, A. (2012), "What we know and don't know about corporate social responsibility: a review and research agenda", Journal of Management, Vol. 38 No. 4, pp. 932-968.

Ahlin, C. and Jiang, N. (2008), "Can micro-credit bring development", Journal of Development Economics, Vol. 86 No. 1, pp. 1-21.

Benmelech, E. and Frydman, C. (2015), "Military CEOs", Journal of Financial Economics, Vol. 117 No. 1, pp. 43-59.

Bhatt, B., Qureshi, I. and Riaz, S. (2019), "Social entrepreneurship in non-munificent institutional environments and implications for institutional work: insights from China", Journal of Business Ethics, Vol. 154 No. 3, pp. 605-630.

Bruton, G. D., Ahlstrom, D. and Li, H. L. (2010), "Institutional theory and entrepreneurship: where are we now and where do we need to move in the future", Entrepreneurship Theory and Practice, Vol. 34 No. 3, pp. 421-440.

Bruton, G. D., Ketchen Jr, D. J. and Ireland, R. D. (2013), "Entrepreneurship as a solution to poverty", Journal of Business Venturing, Vol. 28 No. 6, pp. 683-689.

Bruton, G. D., Khavul, S. and Chavez, H. (2011), "Microlending in emerging economies: building a new line of inquiry from the ground up. Journal of International Business Studies, Vol. 42 No. 5, pp. 718-739.

Cao, F., Sun, J. and Yuan, R. (2019), "Military experience and stock price crash risk: evidence from China", Available at SSRN: http://dx.doi.org/10.2139/ssrn. 3363694.

Donaldson, T. and Preston, L. E. (1995). "The stakeholder theory of the corporation: concepts, evidence, and implications", Academy of Management Review, Vol. 20 No. 1, pp. 65-91.

Du, X. (2017), "Religious belief, corporate philanthropy, and political involvement of entrepreneurs in Chinese family firms", Journal of Business Ethics, Vol. 142 No. 2, pp. 385-406.

Elder, G. H. (1986), “Military times and turning points in men's lives”, Developmental Psychology, Vol. 22 No. 2, pp. 233-245.

Elder, G. H., Gimbel, C. and Ivie, R. (1991), “Turning points in life: the case of military service and war", Military Psychology, Vol. 3 No. 4, pp. 215-231. 
Estrin, S., Mickiewicz, T. and Stephan, U. (2016), "Human capital in social and commercial entrepreneurship", Journal of Business Venturing, Vol. 31 No. 4, pp. 449-467.

Fan, G., Wang, X. L. and Zhu, H. P. (2011), NERI index of marketization of China's provinces 2011 report, Economics Science Press, Beijing. (In Chinese.)

Fletschner, D. and Mesbah, D. (2011), "Gender disparity in access to information: do spouses share what they know", World Development, Vol. 39 No. 8, pp. 14221433.

Gao, Y., Wang, Y. and Zhang, M. (2021), "Who really cares about the environment? CEOs' military service experience and firms' investment in environmental protection", Business Ethics: A European Review, Vol. 30 No. 1, pp. 4-18.

George, G., McGahan, A. M. and Prabhu, J. (2012), "Innovation for inclusive growth: towards a theoretical framework and a research agenda", Journal of Management Studies, Vol. 49 No. 4, pp. 661-683.

Hechavarria, D. M. (2016), "The impact of culture on national prevalence rates of social and commercial entrepreneurship", International Entrepreneurship and Management Journal, Vol. 12 No. 4, pp. 1025-1052.

Hockerts, K. (2017), "Determinants of social entrepreneurial intentions", Entrepreneurship Theory and Practice, Vol. 41 No. 1, pp. 105-130.

Hörisch, J., Kollat, J. and Brieger, S. A. (2017), "What influences environmental entrepreneurship? a multilevel analysis of the determinants of entrepreneurs' environmental orientation", Small Business Economics, Vol. 48 No. 1, pp. 47-69.

Katre, A. and Salipante, P. (2012), "Start-up social ventures: blending fine-grained behaviors from two institutions for entrepreneurial success", Entrepreneurship Theory and Practice, Vol. 36 No. 5, pp. 967-994.

Kimmitt, J., Muñoz, P. and Newbery, R. (2020), "Poverty and the varieties of entrepreneurship in the pursuit of prosperity", Journal of Business Venturing, Vol. 5 No. 4, pp. 1-18.

Koch-Bayram, I. F. and Wernicke, G. (2018), "Drilled to obey? ex-military CEOs and financial misconduct”, Strategic Management Journal, Vol. 39 No. 11, pp. 29432964.

Lan, H., Zhu, Y., Ness, D., Xing, K. and Schneider, K. (2014), "The role and characteristics of social entrepreneurs in contemporary rural cooperative development in China: case studies of rural social entrepreneurship", Asia Pacific Business Review, Vol. 20 No. 3, pp. 379-400.

Law, K. K. and Mills, L. F. (2017), "Military experience and corporate tax avoidance", Review of Accounting Studies, Vol. 22 No. 1, pp. 141-184.

Liu, Z., Xu, Z., Zhou, Z. and Li, Y. (2019), "Buddhist entrepreneurs and new venture performance: the mediating role of entrepreneurial risk-taking", Small Business Economics, Vol. 52 No. 3, pp. 713-727.

Lortie, J., Castrogiovanni, G. J. and Cox, K. C. (2017), "Gender, social salience, and social performance: how women pursue and perform in social ventures", Entrepreneurship \& Regional Development, Vol. 29 No. 1-2, pp. 155-173.

Luo, J. H., Xiang, Y. and Zhu, R. (2017), "Military top executives and corporate 
philanthropy: evidence from China", Asia Pacific Journal of Management, Vol. 34 No. 3, pp. 725-755.

Mair, J., Marti, I. and Ventresca, M. J. (2012), "Building inclusive markets in rural Bangladesh: how intermediaries work institutional voids", Academy of Management Journal, Vol. 55 No. 4, pp. 819-850.

Mair, J. and Noboa, E. (2006), "Social entrepreneurship: how intentions to create a social venture get formed”, In J. Mair, J. Robinson, \& K. Hockerts (Eds.), Social entrepreneurship (pp. 121-136). New York: Palgrave MacMillan.

Marquis, C. and Lee, M. (2013). "Who is governing whom? Executives, governance, and the structure of generosity in large US firms", Strategic Management Journal, Vol. 34 No. 4, pp. 483-497.

Marquis, C. and Qiao, K. (2020), “Waking from Mao's dream: communist ideological imprinting and the internationalization of entrepreneurial ventures in China", Administrative Science Quarterly, Vol. 65 No. 3, pp. 795-830.

Marquis, C. and Tilcsik, A. (2013), "Imprinting: toward a multilevel theory", Academy of Management Annals, Vol. 7 No. 1, pp. 195-245.

Mazereeuw-van der Duijn Schouten, C., Graafland, J. and Kaptein, M. (2014), "Religiosity, CSR attitudes, and CSR behavior: an empirical study of executives' religiosity and CSR", Journal of Business Ethics, Vol. 123 No. 3, pp. 437-459.

Miller, T. L., Grimes, M. G., McMullen, J. S. and Vogus, T. J. (2012), "Venturing for others with heart and head: how compassion encourages social entrepreneurship", Academy of Management Review, Vol. 37 No. 4, pp. 616-640.

Nga, J. K. H. and Shamuganathan, G. (2010), "The influence of personality traits and demographic factors on social entrepreneurship start up intentions", Journal of Business Ethics, Vol. 95 No. 2 pp. 259-282.

Peredo, A. M. and Chrisman, J. J. (2006), "Toward a theory of community-based enterprise", Academy of Management Review, Vol. 31 No. 2 pp. 309-328.

Poon, P. S., Zhou, L. and Chan, T. S. (2009), "Social entrepreneurship in a transitional economy: a critical assessment of rural Chinese entrepreneurial firms", Journal of Management Development, Vol. 28 No. 2 pp. 94-109.

Randøy, T., Strøm, R. Ø. and Mersland, R. (2015), “The impact of entrepreneur-CEOs in microfinance institutions: a global survey", Entrepreneurship Theory and Practice, Vol. 39 No. 4 pp. 927-953.

Renko, M. (2013), "Early challenges of nascent social entrepreneurs", Entrepreneurship Theory and Practice, Vol. 37 No. 5 pp. 1045-1069.

Rindova, V., Barry, D. and Ketchen Jr, D. J. (2009), "Entrepreneuring as emancipation”, Academy of Management Review, Vol. 34 No. 3 pp. 477-491.

Shakya, Y. B. and Rankin, K. N. (2008), "The politics of subversion in development practice: an exploration of microfinance in Nepal and Vietnam", The Journal of Development Studies, Vol. 44 No. 8 pp. 1214-1235.

Singer, A. E. (2006), "Business strategy and poverty alleviation", Journal of Business Ethics, Vol. 66 No. 2-3, pp. 225-231.

Smith, B. R., Kistruck, G. M. and Cannatelli, B. (2016), "The impact of moral intensity and desire for control on scaling decisions in social entrepreneurship", Journal of 
Business Ethics, Vol. 133 No. 4, pp. 677-689.

Stevens, R., Moray, N., Bruneel, J. and Clarysse, B. (2015), "Attention allocation to multiple goals: the case of for-profit social enterprises", Strategic Management Journal, Vol. 36 No. 7, pp. 1006-1016.

Sutter, C., Bruton, G. D. and Chen, J. (2019), "Entrepreneurship as a solution to extreme poverty: a review and future research directions", Journal of Business Venturing, Vol. 34 No. 1, pp. 197-214.

Sutter, C. J., Kistruck, G. M. and Morris, S. (2014), "Adaptations to knowledge templates in base-of-the-pyramid markets: the role of social interaction", Strategic Entrepreneurship Journal, Vol. 8 No. 4, pp. 303-320.

Wang, H. and Qian, C. (2011), "Corporate philanthropy and corporate financial performance: the roles of stakeholder response and political access", Academy of Management Journal, Vol. 54 No. 4, pp. 1159-1181.

$\mathrm{Wu}$, J. and Si, S. (2018), "Poverty reduction through entrepreneurship: incentives, social networks, and sustainability", Asian Business \& Management, Vol. 17 No. 4, pp. 243-259.

Wu, Y. J., Wu, T. and Sharpe, J. (2020), "Consensus on the definition of social entrepreneurship: a content analysis approach", Management Decision, Vol. 58 No. 12, pp. 2593-2619.

Yiu, D. W., Wan, W. P., Ng, F. W., Chen, X. and Su, J. (2014), "Sentimental drivers of social entrepreneurship: a study of China's Guangcai (Glorious) Program", Management and Organization Review, Vol. 10 No. 1, pp. 55-80.

$\mathrm{Yu}, \mathrm{X}$. (2013), "The governance of social enterprises in China", Social Enterprise Journal, Vol. 9 No. 3, pp. 225-246.

Zhao, H. and Lu, J. (2016), "Contingent value of political capital in bank loan acquisition: evidence from founder-controlled private enterprises in China", Journal of Business Venturing, Vol. 31 No. 2, pp. 153-174. 


\section{Table I}

Descriptive statistics and Pearson correlations

\begin{tabular}{|c|c|c|c|c|c|c|c|c|c|c|c|c|c|c|c|c|c|c|c|}
\hline Variables & Mean & SD & 1 & 2 & 3 & 4 & 5 & 6 & 7 & 8 & 9 & 10 & 11 & 12 & 13 & 14 & 15 & 16 & 17 \\
\hline 1. PE1 & 0.123 & 0.329 & 1.000 & & & & & & & & & & & & & & & & \\
\hline 2. PE2 & 0.141 & 0.398 & $0.949^{* *}$ & 1.000 & & & & & & & & & & & & & & & \\
\hline 3. Military experience & 0.047 & 0.211 & $0.030^{*}$ & $0.038^{*}$ & 1.000 & & & & & & & & & & & & & & \\
\hline 4. Corporate philanthropy 1 & 3.207 & 0.712 & $0.051^{* *}$ & $0.044^{*}$ & -0.023 & 1.000 & & & & & & & & & & & & & \\
\hline 5. Government intervention & 7.054 & 2.746 & $-0.100^{* *}$ & $-0.095^{* *}$ & 0.001 & -0.011 & 1.000 & & & & & & & & & & & & \\
\hline 6. Corporate philanthropy 2 & 8.708 & 4.575 & $0.195^{* *}$ & $0.196^{* *}$ & 0.006 & $0.126^{* *}$ & $-0.044^{*}$ & 1.000 & & & & & & & & & & & \\
\hline 7. Gender & 0.133 & 0.339 & $-0.038^{*}$ & $-0.035^{+}$ & $-0.064^{* *}$ & -0.022 & 0.026 & $-0.076^{* *}$ & 1.000 & & & & & & & & & & \\
\hline 8. Education & 3.563 & 1.059 & $0.052^{* *}$ & $0.054^{* *}$ & 0.014 & 0.000 & $-0.034^{+}$ & $0.100^{* *}$ & 0.006 & 1.000 & & & & & & & & & \\
\hline 9. Political connections & 0.397 & 0.489 & $0.202^{* *}$ & $0.200^{* *}$ & -0.015 & $0.033^{+}$ & $-0.142^{* *}$ & $0.419^{* *}$ & $-0.069^{* *}$ & $0.124^{* *}$ & 1.000 & & & & & & & & \\
\hline 10. Unemployment experience & 0.048 & 0.214 & -0.014 & -0.015 & 0.008 & -0.001 & -0.027 & $-0.077^{* *}$ & $0.092^{* * *}$ & $-0.046^{*}$ & $-0.070^{* *}$ & 1.000 & & & & & & & \\
\hline 11. Rural poverty experience & 0.139 & 0.345 & 0.017 & 0.017 & -0.022 & 0.011 & 0.029 & $0.050^{* *}$ & $-0.040^{*}$ & $-0.251^{* *}$ & 0.013 & $-0.041^{*}$ & 1.000 & & & & & & \\
\hline 12. Startup location hardship & 0.757 & 0.429 & $0.032^{+}$ & 0.029 & -0.008 & 0.008 & $-0.080^{* *}$ & $0.100^{* *}$ & $-0.072^{* *}$ & $-0.190^{* *}$ & $0.133^{* *}$ & 0.003 & $0.093^{* *}$ & 1.000 & & & & & \\
\hline 13. Firm age & 7.182 & 4.464 & $0.096^{* *}$ & $0.092^{* *}$ & -0.023 & 0.021 & 0.012 & $0.335^{* *}$ & $-0.052^{* *}$ & -0.014 & $0.273^{* *}$ & $-0.075^{* *}$ & $0.046^{*}$ & $0.062^{* *}$ & 1.000 & & & & \\
\hline 14. Firm size & 3.214 & 1.272 & $0.115^{* *}$ & $0.107^{* *}$ & $0.039^{*}$ & $0.066^{* *}$ & -0.003 & $0.342^{* *}$ & $-0.135^{* *}$ & $0.102^{* *}$ & $0.297^{* *}$ & $-0.088^{* *}$ & 0.008 & $0.150^{* *}$ & $0.055^{* *}$ & 1.000 & & & \\
\hline 15. R\&D intensity & 0.404 & 6.465 & 0.010 & 0.010 & -0.013 & -0.004 & -0.011 & $0.058^{* *}$ & -0.013 & $0.045^{*}$ & $0.044^{*}$ & -0.012 & -0.013 & 0.008 & $0.084^{* *}$ & 0.008 & 1.000 & & \\
\hline 16. ROA & 1.354 & 12.137 & 0.011 & 0.009 & -0.011 & 0.026 & -0.024 & $0.071^{* *}$ & -0.018 & 0.015 & $0.060^{* *}$ & -0.019 & 0.018 & 0.025 & $0.119^{* *}$ & $0.050^{* *}$ & $0.167^{* *}$ & 1.000 & \\
\hline 17. Law enforcement & 7.484 & 2.988 & $-0.116^{* *}$ & $-0.114^{* *}$ & 0.003 & $-0.044^{*}$ & $0.766^{* *}$ & $-0.055^{* *}$ & 0.028 & $-0.053^{* *}$ & $-0.184^{* *}$ & $-0.039^{*}$ & $0.063^{* *}$ & $-0.196^{* *}$ & $0.044^{*}$ & $-0.064^{* *}$ & -0.018 & -0.020 & 1.000 \\
\hline 18. GDP growth & 0.078 & 0.673 & -0.019 & -0.029 & $0.044^{*}$ & -0.008 & $0.036^{*}$ & $0.069^{* *}$ & $-0.050^{* *}$ & $-0.068^{* *}$ & $0.033^{+}$ & $-0.040^{*}$ & 0.027 & $0.197^{* *}$ & $0.037^{\circ}$ & $0.129^{* *}$ & -0.015 & 0.001 & $-0.075^{* *}$ \\
\hline
\end{tabular}

Notes: $\mathrm{N}=3061 .{ }^{* *} \mathrm{p}<0.01,{ }^{*} \mathrm{p}<0.05,{ }^{+} \mathrm{p}<0.1$. 
Table II

Logit models of the moderating role of corporate philanthropy 1 and government intervention between military experience and poverty-reduction entrepreneurship 1

\begin{tabular}{|c|c|c|c|c|}
\hline & $\begin{array}{c}\text { Model 1 } \\
(\mathrm{DV}=\text { PE1) }\end{array}$ & $\begin{array}{c}\text { Model } 2 \\
(\mathrm{DV}=\text { PE1) }\end{array}$ & $\begin{array}{c}\text { Model 3 } \\
\text { (DV=PE1) }\end{array}$ & $\begin{array}{c}\text { Model } 4 \\
\text { (DV=PE1) }\end{array}$ \\
\hline Gender & $\begin{array}{l}-0.185 \\
(0.190)\end{array}$ & $\begin{array}{l}-0.164 \\
(0.190)\end{array}$ & $\begin{array}{l}-0.172 \\
(0.191)\end{array}$ & $\begin{array}{l}-0.166 \\
(0.190)\end{array}$ \\
\hline Education & $\begin{array}{c}0.080 \\
(0.056)\end{array}$ & $\begin{array}{c}0.077 \\
(0.057)\end{array}$ & $\begin{array}{c}0.087 \\
(0.057)\end{array}$ & $\begin{array}{c}0.077 \\
(0.057)\end{array}$ \\
\hline Political connections & $\begin{array}{l}0.915^{* *} \\
(0.128)\end{array}$ & $\begin{array}{l}0.921^{* *} \\
(0.128)\end{array}$ & $\begin{array}{l}0.915^{* *} \\
(0.128)\end{array}$ & $\begin{array}{l}0.931^{* *} \\
(0.129)\end{array}$ \\
\hline Unemployment experience & $\begin{array}{c}0.089 \\
(0.289)\end{array}$ & $\begin{array}{c}0.081 \\
(0.290)\end{array}$ & $\begin{array}{c}0.067 \\
(0.291)\end{array}$ & $\begin{array}{c}0.067 \\
(0.290)\end{array}$ \\
\hline Rural poverty experience & $\begin{array}{c}0.193 \\
(0.166)\end{array}$ & $\begin{array}{c}0.198 \\
(0.166)\end{array}$ & $\begin{array}{c}0.214 \\
(0.167)\end{array}$ & $\begin{array}{c}0.201 \\
(0.166)\end{array}$ \\
\hline Startup location hardship & $\begin{array}{l}-0.024 \\
(0.148)\end{array}$ & $\begin{array}{l}-0.018 \\
(0.148)\end{array}$ & $\begin{array}{l}-0.022 \\
(0.148)\end{array}$ & $\begin{array}{l}-0.008 \\
(0.148)\end{array}$ \\
\hline Firm age & $\begin{array}{l}0.040^{* *} \\
(0.013)\end{array}$ & $\begin{array}{l}0.041^{* *} \\
(0.013)\end{array}$ & $\begin{array}{l}0.041^{\text {** }} \\
(0.013)\end{array}$ & $\begin{array}{l}0.041^{* *} \\
(0.013)\end{array}$ \\
\hline Firm size & $\begin{array}{l}0.152^{* *} \\
(0.045)\end{array}$ & $\begin{array}{l}0.148^{* *} \\
(0.045)\end{array}$ & $\begin{array}{l}0.149^{* *} \\
(0.046)\end{array}$ & $\begin{array}{l}0.149^{* *} \\
(0.046)\end{array}$ \\
\hline $\mathrm{R} \& \mathrm{D}$ intensity & $\begin{array}{l}-0.001 \\
(0.007)\end{array}$ & $\begin{array}{l}-0.001 \\
(0.007)\end{array}$ & $\begin{array}{l}-0.001 \\
(0.007)\end{array}$ & $\begin{array}{l}-0.001 \\
(0.007)\end{array}$ \\
\hline ROA & $\begin{array}{l}-0.003 \\
(0.004)\end{array}$ & $\begin{array}{l}-0.003 \\
(0.004)\end{array}$ & $\begin{array}{l}-0.003 \\
(0.004)\end{array}$ & $\begin{array}{l}-0.003 \\
(0.004)\end{array}$ \\
\hline Law enforcement & $\begin{array}{c}-0.094^{* *} \\
(0.032)\end{array}$ & $\begin{array}{c}-0.096^{* *} \\
(0.032)\end{array}$ & $\begin{array}{c}-0.100^{* *} \\
(0.032)\end{array}$ & $\begin{array}{c}-0.100^{* *} \\
(0.032)\end{array}$ \\
\hline GDP growth & $\begin{array}{c}-0.136 \\
(0.094)\end{array}$ & $\begin{array}{c}-0.144 \\
(0.095)\end{array}$ & $\begin{array}{l}-0.139 \\
(0.094)\end{array}$ & $\begin{array}{l}-0.152 \\
(0.095)\end{array}$ \\
\hline Corporate philanthropy 1 & $\begin{array}{l}0.178^{*} \\
(0.086)\end{array}$ & $\begin{array}{c}0.182^{*} \\
(0.086)\end{array}$ & $\begin{array}{l}0.221^{* *} \\
(0.088)\end{array}$ & $\begin{array}{l}0.186^{*} \\
(0.086)\end{array}$ \\
\hline Government intervention & $\begin{array}{l}-0.012 \\
(0.030)\end{array}$ & $\begin{array}{c}-0.011 \\
(0.030)\end{array}$ & $\begin{array}{l}-0.008 \\
(0.030)\end{array}$ & $\begin{array}{l}-0.001 \\
(0.032)\end{array}$ \\
\hline Military experience & & $\begin{array}{c}0.483^{*} \\
(0.242)\end{array}$ & $\begin{array}{c}0.423^{*} \\
(0.249)\end{array}$ & $\begin{array}{l}0.398^{+} \\
(0.256)\end{array}$ \\
\hline Military experience $\times$ & & & $-0.636^{* *}$ & \\
\hline Corporate philanthropy & & & $(0.251)$ & \\
\hline $\begin{array}{l}\text { Military experience } \times \\
\text { Government intervention }\end{array}$ & & & & $\begin{array}{l}-0.144^{*} \\
(0.077)\end{array}$ \\
\hline Constant & $\begin{array}{l}-3.349^{* *} \\
(0.443)\end{array}$ & $\begin{array}{c}-3.381^{* *} \\
(0.443)\end{array}$ & $\begin{array}{l}-3.533^{* *} \\
(0.451)\end{array}$ & $\begin{array}{c}-3.440^{* *} \\
(0.446)\end{array}$ \\
\hline Observations & 3,061 & 3,061 & 3,061 & 3,061 \\
\hline
\end{tabular}

Notes: 18 industry dummies and 30 province dummies are included in all estimations but not reported in the table. Standard errors appear in parentheses (one-tailed tests for hypothesized variables, two-tailed tests for controls). ${ }^{* *} \mathrm{p}<0.01,{ }^{*} \mathrm{p}<0.05,{ }^{+} \mathrm{p}<0.1$. 


\section{Table III}

Robustness result 1: Probit models of the moderating role of corporate philanthropy 1 and government intervention between military experience and poverty-reduction entrepreneurship 1

\begin{tabular}{|c|c|c|c|c|}
\hline & $\begin{array}{c}\text { Model 1 } \\
(\text { DV=PE1) }\end{array}$ & $\begin{array}{c}\text { Model } 2 \\
(\mathrm{DV}=\text { PE1) }\end{array}$ & $\begin{array}{c}\text { Model } 3 \\
(\text { DV=PE1) }\end{array}$ & $\begin{array}{c}\text { Model } 4 \\
(\mathrm{DV}=\text { PE1) }\end{array}$ \\
\hline Gender & $\begin{array}{c}-0.082 \\
(0.098)\end{array}$ & $\begin{array}{c}-0.071 \\
(0.098)\end{array}$ & $\begin{array}{c}-0.078 \\
(0.099)\end{array}$ & $\begin{array}{c}-0.071 \\
(0.098)\end{array}$ \\
\hline Education & $\begin{array}{c}0.042 \\
(0.030)\end{array}$ & $\begin{array}{c}0.041 \\
(0.031)\end{array}$ & $\begin{array}{c}0.046 \\
(0.031)\end{array}$ & $\begin{array}{c}0.040 \\
(0.031)\end{array}$ \\
\hline Political connections & $\begin{array}{l}0.489^{* *} \\
(0.067)\end{array}$ & $\begin{array}{l}0.492^{* *} \\
(0.067)\end{array}$ & $\begin{array}{l}0.487^{* *} \\
(0.067)\end{array}$ & $\begin{array}{l}0.498^{* *} \\
(0.067)\end{array}$ \\
\hline Unemployment experience & $\begin{array}{c}0.030 \\
(0.153)\end{array}$ & $\begin{array}{c}0.026 \\
(0.153)\end{array}$ & $\begin{array}{c}0.023 \\
(0.153)\end{array}$ & $\begin{array}{c}0.017 \\
(0.154)\end{array}$ \\
\hline Rural poverty experience & $\begin{array}{c}0.112 \\
(0.090)\end{array}$ & $\begin{array}{c}0.115 \\
(0.090)\end{array}$ & $\begin{array}{c}0.123 \\
(0.090)\end{array}$ & $\begin{array}{c}0.115 \\
(0.090)\end{array}$ \\
\hline Startup location hardship & $\begin{array}{l}-0.016 \\
(0.078)\end{array}$ & $\begin{array}{c}-0.011 \\
(0.078)\end{array}$ & $\begin{array}{l}-0.012 \\
(0.078)\end{array}$ & $\begin{array}{l}-0.007 \\
(0.078)\end{array}$ \\
\hline Firm age & $\begin{array}{l}0.022^{* *} \\
(0.007)\end{array}$ & $\begin{array}{l}0.023^{* *} \\
(0.007)\end{array}$ & $\begin{array}{l}0.023^{* *} \\
(0.007)\end{array}$ & $\begin{array}{l}0.023^{* *} \\
(0.007)\end{array}$ \\
\hline Firm size & $\begin{array}{l}0.086^{* *} \\
(0.025)\end{array}$ & $\begin{array}{l}0.084^{* *} \\
(0.025)\end{array}$ & $\begin{array}{l}0.084^{* *} \\
(0.025)\end{array}$ & $\begin{array}{l}0.084^{* *} \\
(0.025)\end{array}$ \\
\hline R\&D intensity & $\begin{array}{l}-0.001 \\
(0.004)\end{array}$ & $\begin{array}{l}-0.001 \\
(0.004)\end{array}$ & $\begin{array}{l}-0.001 \\
(0.004)\end{array}$ & $\begin{array}{l}-0.001 \\
(0.004)\end{array}$ \\
\hline $\mathrm{ROA}$ & $\begin{array}{l}-0.002 \\
(0.003)\end{array}$ & $\begin{array}{l}-0.002 \\
(0.002)\end{array}$ & $\begin{array}{l}-0.002 \\
(0.002)\end{array}$ & $\begin{array}{l}-0.002 \\
(0.002)\end{array}$ \\
\hline Law enforcement & $\begin{array}{l}-0.048^{* *} \\
(0.017)\end{array}$ & $\begin{array}{l}-0.049^{* *} \\
(0.017)\end{array}$ & $\begin{array}{l}-0.051^{* *} \\
(0.017)\end{array}$ & $\begin{array}{l}-0.051^{* *} \\
(0.017)\end{array}$ \\
\hline GDP growth & $\begin{array}{l}-0.064 \\
(0.047)\end{array}$ & $\begin{array}{l}-0.068 \\
(0.047)\end{array}$ & $\begin{array}{l}-0.068 \\
(0.047)\end{array}$ & $\begin{array}{l}-0.074 \\
(0.047)\end{array}$ \\
\hline Corporate philanthropy 1 & $\begin{array}{l}0.095^{*} \\
(0.044)\end{array}$ & $\begin{array}{l}0.099^{*} \\
(0.044)\end{array}$ & $\begin{array}{l}0.117^{* *} \\
(0.045)\end{array}$ & $\begin{array}{l}0.099^{*} \\
(0.044)\end{array}$ \\
\hline Government intervention & $\begin{array}{l}-0.008 \\
(0.016)\end{array}$ & $\begin{array}{l}-0.007 \\
(0.016)\end{array}$ & $\begin{array}{l}-0.005 \\
(0.017)\end{array}$ & $\begin{array}{l}-0.003 \\
(0.017)\end{array}$ \\
\hline Military experience & & $\begin{array}{c}0.266^{*} \\
(0.133)\end{array}$ & $\begin{array}{l}0.229^{*} \\
(0.137)\end{array}$ & $\begin{array}{c}0.240^{*} \\
(0.137)\end{array}$ \\
\hline Military experience $\times$ & & & $-0.340^{* *}$ & \\
\hline Corporate philanthropy & & & $(0.145)$ & \\
\hline Military experience $\times$ & & & & $-0.075^{*}$ \\
\hline Government intervention & & & & $(0.041)$ \\
\hline Constant & $\begin{array}{c}-1.907^{* *} \\
(0.233)\end{array}$ & $\begin{array}{c}-1.935^{* *} \\
(0.234)\end{array}$ & $\begin{array}{l}-2.005^{* *} \\
(0.237)\end{array}$ & $\begin{array}{c}-1.954^{* *} \\
(0.234)\end{array}$ \\
\hline Observations & 3,061 & 3,061 & 3,061 & 3,061 \\
\hline
\end{tabular}




\section{Table IV}

Robustness result 2: Ordered Logit models of the moderating role of corporate philanthropy 1 and government intervention between military experience and povertyreduction entrepreneurship 2

\begin{tabular}{|c|c|c|c|c|}
\hline & $\begin{array}{c}\text { Model } 1 \\
\text { (DV=PE2) } \\
\end{array}$ & $\begin{array}{c}\text { Model 2 } \\
\text { (DV=PE2) }\end{array}$ & $\begin{array}{c}\text { Model 3 } \\
\text { (DV=PE2) } \\
\end{array}$ & $\begin{array}{c}\text { Model } 4 \\
\text { (DV=PE2) } \\
\end{array}$ \\
\hline Gender & $\begin{array}{l}-0.183 \\
(0.190)\end{array}$ & $\begin{array}{l}-0.162 \\
(0.190)\end{array}$ & $\begin{array}{l}-0.171 \\
(0.190)\end{array}$ & $\begin{array}{l}-0.163 \\
(0.190)\end{array}$ \\
\hline Education & $\begin{array}{c}0.082 \\
(0.056)\end{array}$ & $\begin{array}{c}0.080 \\
(0.056)\end{array}$ & $\begin{array}{c}0.089 \\
(0.056)\end{array}$ & $\begin{array}{c}0.080 \\
(0.056)\end{array}$ \\
\hline Political connections & $\begin{array}{l}0.920^{* *} \\
(0.128)\end{array}$ & $\begin{array}{l}0.929^{* *} \\
(0.128)\end{array}$ & $\begin{array}{l}0.921^{* *} \\
(0.128)\end{array}$ & $\begin{array}{l}0.935^{* *} \\
(0.128)\end{array}$ \\
\hline Unemployment experience & $\begin{array}{c}0.078 \\
(0.289)\end{array}$ & $\begin{array}{c}0.068 \\
(0.289)\end{array}$ & $\begin{array}{c}0.055 \\
(0.290)\end{array}$ & $\begin{array}{c}0.056 \\
(0.290)\end{array}$ \\
\hline Rural poverty experience & $\begin{array}{c}0.208 \\
(0.165)\end{array}$ & $\begin{array}{c}0.216 \\
(0.166)\end{array}$ & $\begin{array}{c}0.231 \\
(0.166)\end{array}$ & $\begin{array}{c}0.221 \\
(0.165)\end{array}$ \\
\hline Startup location hardship & $\begin{array}{l}-0.020 \\
(0.147)\end{array}$ & $\begin{array}{l}-0.010 \\
(0.147)\end{array}$ & $\begin{array}{l}-0.015 \\
(0.147)\end{array}$ & $\begin{array}{c}0.001 \\
(0.148)\end{array}$ \\
\hline Firm age & $\begin{array}{l}0.040^{* *} \\
(0.013)\end{array}$ & $\begin{array}{l}0.041^{* *} \\
(0.013)\end{array}$ & $\begin{array}{l}0.040^{* *} \\
(0.013)\end{array}$ & $\begin{array}{l}0.041^{* *} \\
(0.013)\end{array}$ \\
\hline Firm size & $\begin{array}{l}0.153^{* *} \\
(0.045)\end{array}$ & $\begin{array}{l}0.148^{* *} \\
(0.046)\end{array}$ & $\begin{array}{l}0.149^{* *} \\
(0.046)\end{array}$ & $\begin{array}{l}0.149^{* *} \\
(0.046)\end{array}$ \\
\hline R\&D intensity & $\begin{array}{l}-0.001 \\
(0.007)\end{array}$ & $\begin{array}{l}-0.001 \\
(0.007)\end{array}$ & $\begin{array}{l}-0.001 \\
(0.007)\end{array}$ & $\begin{array}{l}-0.001 \\
(0.007)\end{array}$ \\
\hline ROA & $\begin{array}{l}-0.003 \\
(0.004)\end{array}$ & $\begin{array}{l}-0.003 \\
(0.004)\end{array}$ & $\begin{array}{l}-0.003 \\
(0.004)\end{array}$ & $\begin{array}{l}-0.003 \\
(0.004)\end{array}$ \\
\hline Law enforcement & $\begin{array}{c}-0.097^{* *} \\
(0.032)\end{array}$ & $\begin{array}{l}-0.099^{* *} \\
(0.032)\end{array}$ & $\begin{array}{l}-0.103^{* *} \\
(0.032)\end{array}$ & $\begin{array}{l}-0.106^{* *} \\
(0.032)\end{array}$ \\
\hline GDP growth & $\begin{array}{l}-0.148 \\
(0.094)\end{array}$ & $\begin{array}{l}-0.157^{+} \\
(0.095)\end{array}$ & $\begin{array}{l}-0.151 \\
(0.094)\end{array}$ & $\begin{array}{l}-0.164^{+} \\
(0.095)\end{array}$ \\
\hline Corporate philanthropy 1 & $\begin{array}{l}0.172^{*} \\
(0.086)\end{array}$ & $\begin{array}{l}0.176^{*} \\
(0.086)\end{array}$ & $\begin{array}{l}0.216^{* *} \\
(0.088)\end{array}$ & $\begin{array}{l}0.179^{*} \\
(0.086)\end{array}$ \\
\hline Government intervention & $\begin{array}{l}-0.010 \\
(0.030)\end{array}$ & $\begin{array}{l}-0.008 \\
(0.030)\end{array}$ & $\begin{array}{l}-0.005 \\
(0.030)\end{array}$ & $\begin{array}{c}0.004 \\
(0.031)\end{array}$ \\
\hline Military experience & & $\begin{array}{c}0.524^{*} \\
(0.241)\end{array}$ & $\begin{array}{c}0.466^{*} \\
(0.248)\end{array}$ & $\begin{array}{c}0.451^{*} \\
(0.252)\end{array}$ \\
\hline Military experience $\times$ & & & $-0.585^{* *}$ & \\
\hline Corporate philanthropy & & & $(0.243)$ & \\
\hline Military experience $\times$ & & & & $-0.107^{*}$ \\
\hline Government intervention & & & & $(0.062)$ \\
\hline Constant 1 & $\begin{array}{l}3.343^{* *} \\
(0.442)\end{array}$ & $\begin{array}{l}3.380^{* *} \\
(0.442)\end{array}$ & $\begin{array}{l}3.529^{* *} \\
(0.449)\end{array}$ & $\begin{array}{l}3.436^{* *} \\
(0.445)\end{array}$ \\
\hline Constant 2 & $\begin{array}{l}5.429^{* *} \\
(0.461)\end{array}$ & $\begin{array}{l}5.468^{* *} \\
(0.460)\end{array}$ & $\begin{array}{l}5.619^{* *} \\
(0.468)\end{array}$ & $\begin{array}{l}5.529^{* *} \\
(0.464)\end{array}$ \\
\hline Observations & 3,061 & 3,061 & 3,061 & 3,061 \\
\hline
\end{tabular}

Notes: 18 industry dummies and 30 province dummies are included in all estimations but not reported in the table. Standard errors appear in parentheses (one-tailed tests for hypothesized variables, two-tailed tests for controls). ${ }^{* *} \mathrm{p}<0.01,{ }^{*} \mathrm{p}<0.05,{ }^{+} \mathrm{p}<0.1$. 
Table V

Robustness result 3: Logit models of the moderating role of corporate philanthropy 2 between military experience and poverty-reduction entrepreneurship 1

\begin{tabular}{|c|c|c|c|}
\hline & $\begin{array}{c}\text { Model 1 } \\
(\mathrm{DV}=\text { PE1) }\end{array}$ & $\begin{array}{c}\text { Model } 2 \\
\text { (DV=PE1) }\end{array}$ & $\begin{array}{c}\text { Model } 3 \\
\text { (DV=PE1) }\end{array}$ \\
\hline Gender & $\begin{array}{l}-0.177 \\
(0.192)\end{array}$ & $\begin{array}{l}-0.156 \\
(0.192)\end{array}$ & $\begin{array}{l}-0.151 \\
(0.192)\end{array}$ \\
\hline Education & $\begin{array}{c}0.036 \\
(0.057)\end{array}$ & $\begin{array}{c}0.034 \\
(0.057)\end{array}$ & $\begin{array}{c}0.035 \\
(0.057)\end{array}$ \\
\hline Political connections & $\begin{array}{l}0.616^{* *} \\
(0.133)\end{array}$ & $\begin{array}{l}0.624^{* *} \\
(0.133)\end{array}$ & $\begin{array}{l}0.616^{* *} \\
(0.133)\end{array}$ \\
\hline Unemployment experience & $\begin{array}{c}0.115 \\
(0.294)\end{array}$ & $\begin{array}{c}0.108 \\
(0.294)\end{array}$ & $\begin{array}{c}0.090 \\
(0.294)\end{array}$ \\
\hline Rural poverty experience & $\begin{array}{c}0.146 \\
(0.167)\end{array}$ & $\begin{array}{c}0.150 \\
(0.167)\end{array}$ & $\begin{array}{c}0.151 \\
(0.167)\end{array}$ \\
\hline Startup location hardship & $\begin{array}{l}-0.028 \\
(0.149)\end{array}$ & $\begin{array}{l}-0.021 \\
(0.149)\end{array}$ & $\begin{array}{l}-0.026 \\
(0.149)\end{array}$ \\
\hline Firm age & $\begin{array}{c}0.015 \\
(0.013)\end{array}$ & $\begin{array}{c}0.016 \\
(0.013)\end{array}$ & $\begin{array}{c}0.014 \\
(0.013)\end{array}$ \\
\hline Firm size & $\begin{array}{c}0.069 \\
(0.047)\end{array}$ & $\begin{array}{c}0.066 \\
(0.047)\end{array}$ & $\begin{array}{c}0.064 \\
(0.047)\end{array}$ \\
\hline $\mathrm{R} \& \mathrm{D}$ intensity & $\begin{array}{l}-0.003 \\
(0.007)\end{array}$ & $\begin{array}{l}-0.003 \\
(0.007)\end{array}$ & $\begin{array}{l}-0.003 \\
(0.007)\end{array}$ \\
\hline ROA & $\begin{array}{l}-0.004 \\
(0.004)\end{array}$ & $\begin{array}{l}-0.003 \\
(0.004)\end{array}$ & $\begin{array}{l}-0.003 \\
(0.004)\end{array}$ \\
\hline Law enforcement & $\begin{array}{l}-0.113^{* *} \\
(0.032)\end{array}$ & $\begin{array}{l}-0.115^{* *} \\
(0.032)\end{array}$ & $\begin{array}{l}-0.114^{* *} \\
(0.032)\end{array}$ \\
\hline GDP growth & $\begin{array}{l}-0.148 \\
(0.098)\end{array}$ & $\begin{array}{l}-0.158 \\
(0.098)\end{array}$ & $\begin{array}{l}-0.152 \\
(0.098)\end{array}$ \\
\hline Corporate philanthropy 2 & $\begin{array}{l}0.141^{* *} \\
(0.022)\end{array}$ & $\begin{array}{l}0.140^{* *} \\
(0.022)\end{array}$ & $\begin{array}{l}0.149^{* *} \\
(0.023)\end{array}$ \\
\hline Government intervention & $\begin{array}{c}0.003 \\
(0.030)\end{array}$ & $\begin{array}{c}0.004 \\
(0.030)\end{array}$ & $\begin{array}{c}0.003 \\
(0.030)\end{array}$ \\
\hline Military experience & & $\begin{array}{c}0.475^{*} \\
(0.244)\end{array}$ & $\begin{array}{l}0.671^{* *} \\
(0.244)\end{array}$ \\
\hline $\begin{array}{l}\text { Military experience } \times \\
\text { Cornorate philanthropy } 2\end{array}$ & & & $\begin{array}{l}-0.138^{* *} \\
(0.056)\end{array}$ \\
\hline Corporate philanthropy 2 & $\begin{array}{l}-3.342^{* *} \\
(0.367)\end{array}$ & $\begin{array}{l}-3.367^{* *} \\
(0.368)\end{array}$ & $\begin{array}{c}(0.056) \\
-3.440^{* *} \\
(0.372)\end{array}$ \\
\hline Observations & 3,061 & 3,061 & 3,061 \\
\hline
\end{tabular}

Notes: 18 industry dummies and 30 province dummies are included in all estimations but not reported in the table. Standard errors appear in parentheses (one-tailed tests for hypothesized variables, two-tailed tests for controls). ${ }^{* *} \mathrm{p}<0.01,{ }^{*} \mathrm{p}<0.05,{ }^{+} \mathrm{p}<0.1$. 
Table VI

Robustness result 4: Ivprobit models of the relationship between military experience and poverty-reduction entrepreneurship 1

\begin{tabular}{|c|c|c|}
\hline & $\begin{array}{c}\text { Model 1 } \\
\text { (DV= Military experience) }\end{array}$ & $\begin{array}{c}\text { Model } 2 \\
\text { (DV=PE1) }\end{array}$ \\
\hline Gender & $\begin{array}{l}-0.038^{* *} \\
(0.011)\end{array}$ & $\begin{array}{l}0.155^{*} \\
(0.069)\end{array}$ \\
\hline Education & $\begin{array}{c}0.002 \\
(0.004)\end{array}$ & $\begin{array}{c}0.006 \\
(0.023)\end{array}$ \\
\hline Political connections & $\begin{array}{l}-0.009 \\
(0.009)\end{array}$ & $\begin{array}{c}0.200 \\
(0.129)\end{array}$ \\
\hline Unemployment experience & $\begin{array}{c}0.017 \\
(0.018)\end{array}$ & $\begin{array}{l}-0.063 \\
(0.096)\end{array}$ \\
\hline Rural poverty experience & $\begin{array}{l}-0.013 \\
(0.011)\end{array}$ & $\begin{array}{c}0.092 \\
(0.064)\end{array}$ \\
\hline Startup location hardship & $\begin{array}{l}-0.008 \\
(0.010)\end{array}$ & $\begin{array}{c}0.034 \\
(0.050)\end{array}$ \\
\hline Firm age & $\begin{array}{l}-0.001 \\
(0.001)\end{array}$ & $\begin{array}{c}0.012 \\
(0.007)\end{array}$ \\
\hline Firm size & $\begin{array}{l}0.006^{*} \\
(0.003)\end{array}$ & $\begin{array}{l}-0.002 \\
(0.029)\end{array}$ \\
\hline R\&D intensity & $\begin{array}{c}0.001 \\
(0.003)\end{array}$ & $\begin{array}{l}-0.001 \\
(0.001)\end{array}$ \\
\hline ROA & $\begin{array}{l}-0.001 \\
(0.001)\end{array}$ & $\begin{array}{c}0.001 \\
(0.002)\end{array}$ \\
\hline Law enforcement & $\begin{array}{l}-0.001 \\
(0.002)\end{array}$ & $\begin{array}{l}-0.021 \\
(0.016)\end{array}$ \\
\hline GDP growth & $\begin{array}{l}0.013^{*} \\
(0.006)\end{array}$ & $\begin{array}{l}-0.083^{*} \\
(0.032)\end{array}$ \\
\hline Corporate philanthropy & $\begin{array}{l}-0.007^{+} \\
(0.005)\end{array}$ & $\begin{array}{l}0.064^{*} \\
(0.036)\end{array}$ \\
\hline Government intervention & $\begin{array}{l}-0.001 \\
(0.002)\end{array}$ & $\begin{array}{c}0.003 \\
(0.011)\end{array}$ \\
\hline $\begin{array}{l}\text { Instrument } \\
\text { Military atmosphere }\end{array}$ & $\begin{array}{l}-0.006^{+} \\
(0.005)\end{array}$ & \\
\hline Instrumented military experience & & $\begin{array}{l}4.598^{* *} \\
(0.345)\end{array}$ \\
\hline Constant & $\begin{array}{l}0.076^{*} \\
(0.030)\end{array}$ & $\begin{array}{l}-0.911^{*} \\
(0.488)\end{array}$ \\
\hline Observations & 3,061 & 3,061 \\
\hline
\end{tabular}

Notes: 18 industry dummies and 30 province dummies are included in all estimations but not reported in the table. Standard errors appear in parentheses (one-tailed tests for hypothesized variables, two-tailed tests for controls). ${ }^{* *} \mathrm{p}<0.01,{ }^{*} \mathrm{p}<0.05,{ }^{+} \mathrm{p}<0.1$. 


\section{Table VII}

The relationship between military experience and numbers of employees from less-developed areas

\begin{tabular}{|c|c|c|}
\hline & $\begin{array}{c}\text { Model } 1 \\
\text { (DV=Numbers of } \\
\text { employees from less- } \\
\text { developed areas) }\end{array}$ & $\begin{array}{c}\text { Model 2 } \\
\text { (DV=Numbers of } \\
\text { employees from less- } \\
\text { developed areas) }\end{array}$ \\
\hline Gender & $\begin{array}{c}20.026 \\
(16.239)\end{array}$ & $\begin{array}{c}21.830 \\
(16.265)\end{array}$ \\
\hline Education & $\begin{array}{c}8.712 \\
(5.493)\end{array}$ & $\begin{array}{c}8.628 \\
(5.491)\end{array}$ \\
\hline Political connections & $\begin{array}{l}36.546^{* *} \\
(12.403)\end{array}$ & $\begin{array}{l}36.978^{* *} \\
(12.401)\end{array}$ \\
\hline Unemployment experience & $\begin{array}{c}9.751 \\
(25.699)\end{array}$ & $\begin{array}{c}9.036 \\
(25.693)\end{array}$ \\
\hline Rural poverty experience & $\begin{array}{c}15.119 \\
(16.329)\end{array}$ & $\begin{array}{c}15.683 \\
(16.327)\end{array}$ \\
\hline Startup location hardship & $\begin{array}{c}4.873 \\
(13.662)\end{array}$ & $\begin{array}{c}5.252 \\
(13.659)\end{array}$ \\
\hline Firm age & $\begin{array}{l}2.833^{*} \\
(1.286)\end{array}$ & $\begin{array}{l}2.875^{*} \\
(1.286)\end{array}$ \\
\hline Firm size & $\begin{array}{l}82.888^{* *} \\
(4.597)\end{array}$ & $\begin{array}{l}82.596^{* *} \\
(4.599)\end{array}$ \\
\hline $\mathrm{R} \& \mathrm{D}$ intensity & $\begin{array}{c}0.101 \\
(0.854)\end{array}$ & $\begin{array}{c}0.116 \\
(0.853)\end{array}$ \\
\hline ROA & $\begin{array}{c}0.892 \\
(0.456)\end{array}$ & $\begin{array}{l}0.898^{*} \\
(0.456)\end{array}$ \\
\hline Law enforcement & $\begin{array}{l}2.858 \\
(2.961)\end{array}$ & $\begin{array}{c}2.807 \\
(2.960)\end{array}$ \\
\hline GDP growth & $\begin{array}{c}0.135 \\
(8.360)\end{array}$ & $\begin{array}{l}-0.497 \\
(8.364)\end{array}$ \\
\hline Corporate philanthropy 1 & $\begin{array}{l}-1.176 \\
(7.651)\end{array}$ & $\begin{array}{l}-0.845 \\
(7.651)\end{array}$ \\
\hline Government intervention & $\begin{array}{c}2.413 \\
(3.130)\end{array}$ & $\begin{array}{c}2.465 \\
(3.129)\end{array}$ \\
\hline Ex-military & & $\begin{array}{l}45.825^{*} \\
(25.808)\end{array}$ \\
\hline Constant & $\begin{array}{l}-297.130^{* *} \\
(40.828)\end{array}$ & $\begin{array}{l}-300.083^{* *} \\
(40.848)\end{array}$ \\
\hline Observations & 3,061 & 3,061 \\
\hline
\end{tabular}

Notes: 18 industry dummies and 30 province dummies are included in all estimations but not reported in the table. Standard errors appear in parentheses (one-tailed tests for hypothesized variables, two-tailed tests for controls). ${ }^{* *} \mathrm{p}<0.01,{ }^{*} \mathrm{p}<0.05,{ }^{+} \mathrm{p}<0.1$. 
Table VIII

The political motivation between military experience and corporate philanthropy

\begin{tabular}{|c|c|c|c|c|}
\hline & $\begin{array}{c}\text { Model } 1 \\
(\mathrm{DV}=\mathbf{P M})\end{array}$ & $\begin{array}{c}\text { Model } 2 \\
(\mathrm{DV}=\mathrm{PM})\end{array}$ & $\begin{array}{c}\text { Model } 3 \\
(\mathrm{DV}=\mathbf{P M})\end{array}$ & $\begin{array}{c}\text { Model } 4 \\
(\mathrm{DV}=\mathrm{PM})\end{array}$ \\
\hline Gender & $\begin{array}{l}-0.015 \\
(0.105)\end{array}$ & $\begin{array}{l}-0.028 \\
(0.105)\end{array}$ & $\begin{array}{l}-0.005 \\
(0.104)\end{array}$ & $\begin{array}{l}-0.009 \\
(0.105)\end{array}$ \\
\hline Education & $\begin{array}{c}0.052 \\
(0.036)\end{array}$ & $\begin{array}{c}0.053 \\
(0.036)\end{array}$ & $\begin{array}{c}0.054 \\
(0.035)\end{array}$ & $\begin{array}{c}0.037 \\
(0.035)\end{array}$ \\
\hline Political connections & $\begin{array}{l}-0.612^{* *} \\
(0.080)\end{array}$ & $\begin{array}{l}-0.615^{* *} \\
(0.080)\end{array}$ & $\begin{array}{l}-0.613^{* *} \\
(0.080)\end{array}$ & $\begin{array}{l}-0.751^{* *} \\
(0.083)\end{array}$ \\
\hline Unemployment experience & $\begin{array}{l}-0.081 \\
(0.166)\end{array}$ & $\begin{array}{l}-0.076 \\
(0.166)\end{array}$ & $\begin{array}{l}-0.087 \\
(0.165)\end{array}$ & $\begin{array}{l}-0.067 \\
(0.165)\end{array}$ \\
\hline Rural poverty experience & $\begin{array}{c}0.053 \\
(0.106)\end{array}$ & $\begin{array}{c}0.049 \\
(0.106)\end{array}$ & $\begin{array}{c}0.045 \\
(0.105)\end{array}$ & $\begin{array}{c}0.021 \\
(0.105)\end{array}$ \\
\hline Startup location hardship & $\begin{array}{l}-0.023 \\
(0.088)\end{array}$ & $\begin{array}{l}-0.026 \\
(0.088)\end{array}$ & $\begin{array}{l}-0.015 \\
(0.088)\end{array}$ & $\begin{array}{l}-0.034 \\
(0.088)\end{array}$ \\
\hline Firm age & $\begin{array}{l}-0.006 \\
(0.008)\end{array}$ & $\begin{array}{l}-0.006 \\
(0.008)\end{array}$ & $\begin{array}{l}-0.007 \\
(0.008)\end{array}$ & $\begin{array}{l}-0.020^{*} \\
(0.009)\end{array}$ \\
\hline Firm size & $\begin{array}{l}0.004 \\
(0.030)\end{array}$ & $\begin{array}{c}0.006 \\
(0.030)\end{array}$ & $\begin{array}{l}-0.008 \\
(0.030)\end{array}$ & $\begin{array}{l}-0.043 \\
(0.031)\end{array}$ \\
\hline$R \& D$ intensity & $\begin{array}{c}0.002 \\
(0.006)\end{array}$ & $\begin{array}{c}0.002 \\
(0.006)\end{array}$ & $\begin{array}{c}0.003 \\
(0.005)\end{array}$ & $\begin{array}{c}0.002 \\
(0.005)\end{array}$ \\
\hline ROA & $\begin{array}{c}0.004 \\
(0.003)\end{array}$ & $\begin{array}{c}0.004 \\
(0.003)\end{array}$ & $\begin{array}{c}0.004 \\
(0.003)\end{array}$ & $\begin{array}{c}0.004 \\
(0.003)\end{array}$ \\
\hline Law enforcement & $\begin{array}{c}0.002 \\
(0.019)\end{array}$ & $\begin{array}{c}0.002 \\
(0.019)\end{array}$ & $\begin{array}{c}0.009 \\
(0.019)\end{array}$ & $\begin{array}{c}0.000 \\
(0.019)\end{array}$ \\
\hline GDP growth & $\begin{array}{l}-0.159^{* *} \\
(0.054)\end{array}$ & $\begin{array}{l}-0.154^{* *} \\
(0.054)\end{array}$ & $\begin{array}{l}-0.150^{* *} \\
(0.054)\end{array}$ & $\begin{array}{c}-0.167^{* *} \\
(0.054)\end{array}$ \\
\hline Government intervention & $\begin{array}{c}0.019 \\
(0.020)\end{array}$ & $\begin{array}{c}0.019 \\
(0.020)\end{array}$ & $\begin{array}{c}0.014 \\
(0.020)\end{array}$ & $\begin{array}{c}0.021 \\
(0.020)\end{array}$ \\
\hline Military experience & & $\begin{array}{l}-0.336^{*} \\
(0.167)\end{array}$ & & \\
\hline Corporate philanthropy 1 & & & $\begin{array}{l}0.345^{* *} \\
(0.049)\end{array}$ & \\
\hline Government philanthropy 2 & & & & $\begin{array}{l}0.055^{* *} \\
(0.009)\end{array}$ \\
\hline Constant & $\begin{array}{l}3.220^{* *} \\
(0.213)\end{array}$ & $\begin{array}{l}3.234^{* *} \\
(0.213)\end{array}$ & $\begin{array}{l}2.126^{* *} \\
(0.262)\end{array}$ & $\begin{array}{l}3.106^{* *} \\
(0.212)\end{array}$ \\
\hline Observations & 3,061 & 3,061 & 3,061 & 3,061 \\
\hline
\end{tabular}

Notes: 18 industry dummies and 30 province dummies are included in all estimations but not reported in the table. Standard errors appear in parentheses (one-tailed tests for hypothesized variables, two-tailed tests for controls). ${ }^{* *} \mathrm{p}<0.01,{ }^{*} \mathrm{p}<0.05,{ }^{+} \mathrm{p}<0.1$. 
Figure 1

Theoretical model

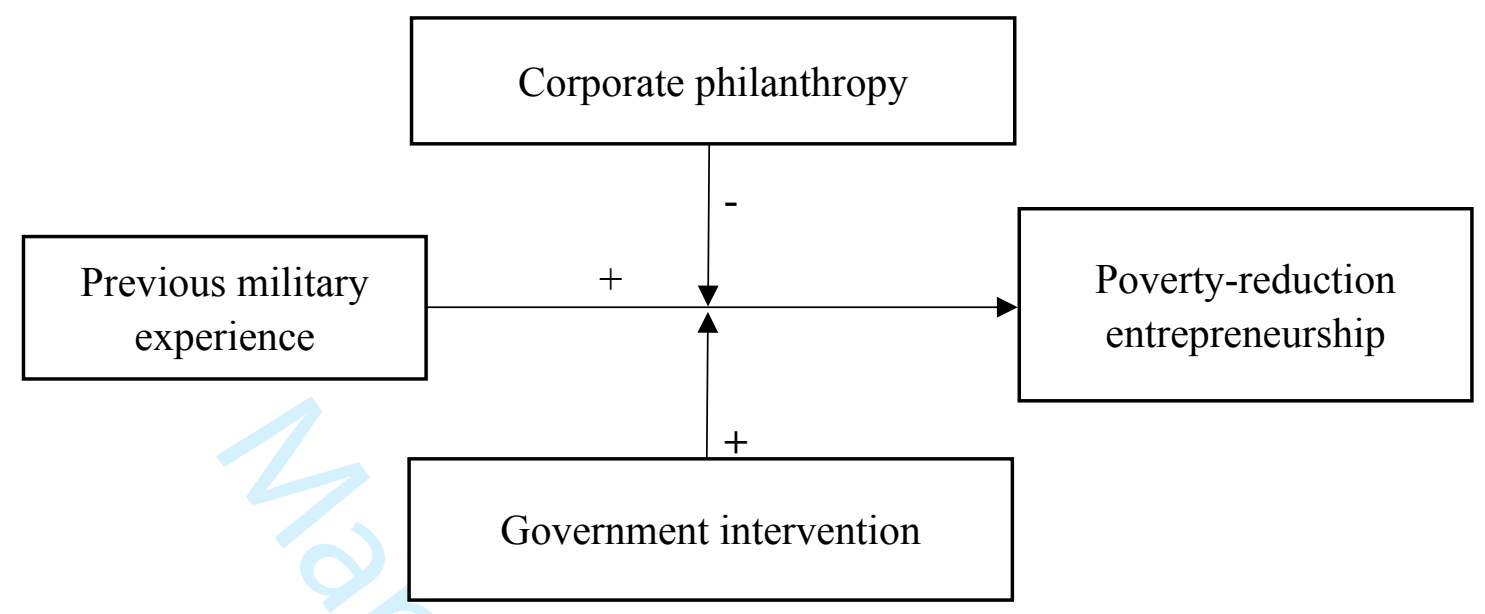


Figure 2

Interaction effect between corporate philanthropy 1 and military experience

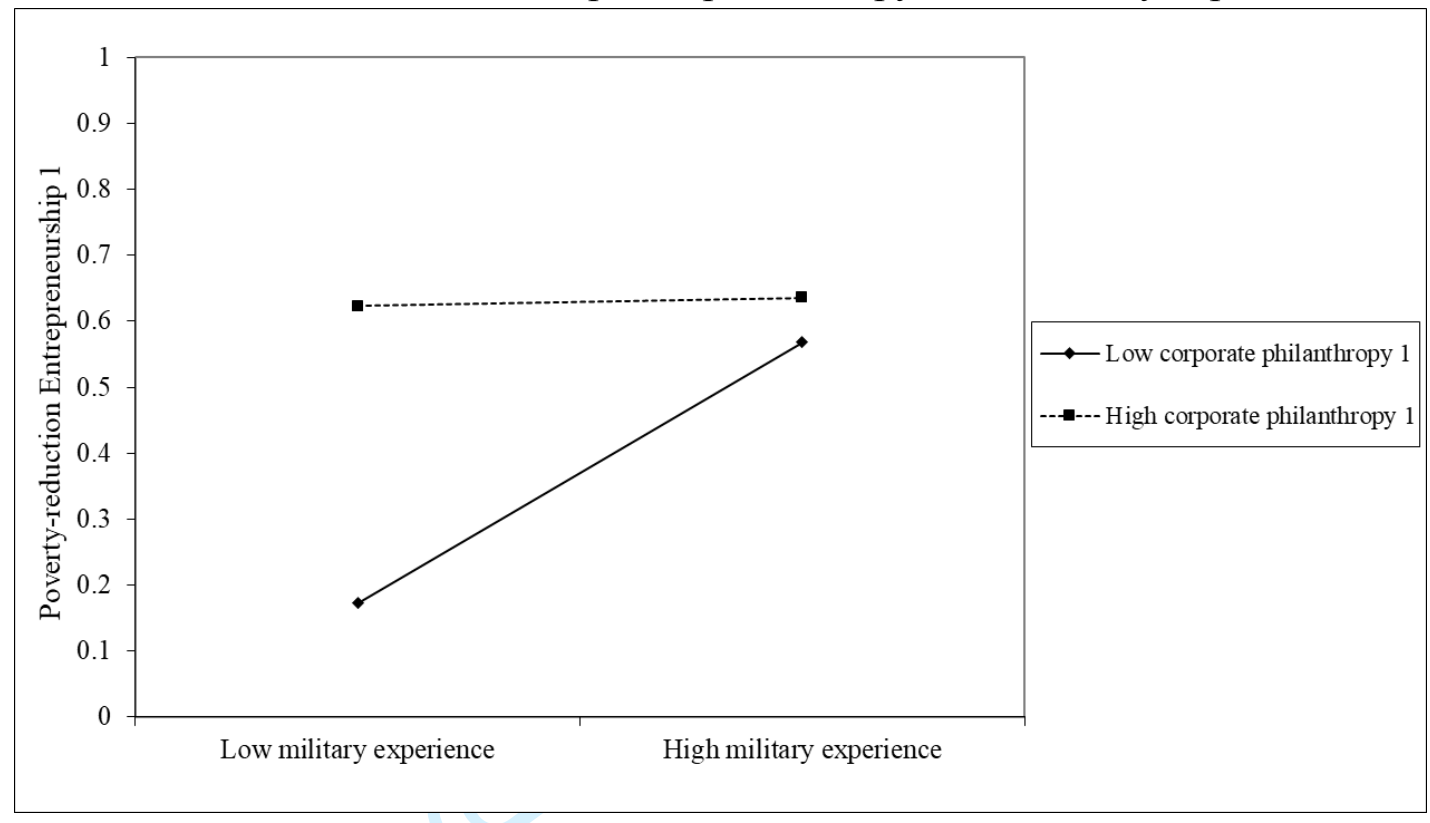

Figure 3

Interaction effect between government intervention and military experience

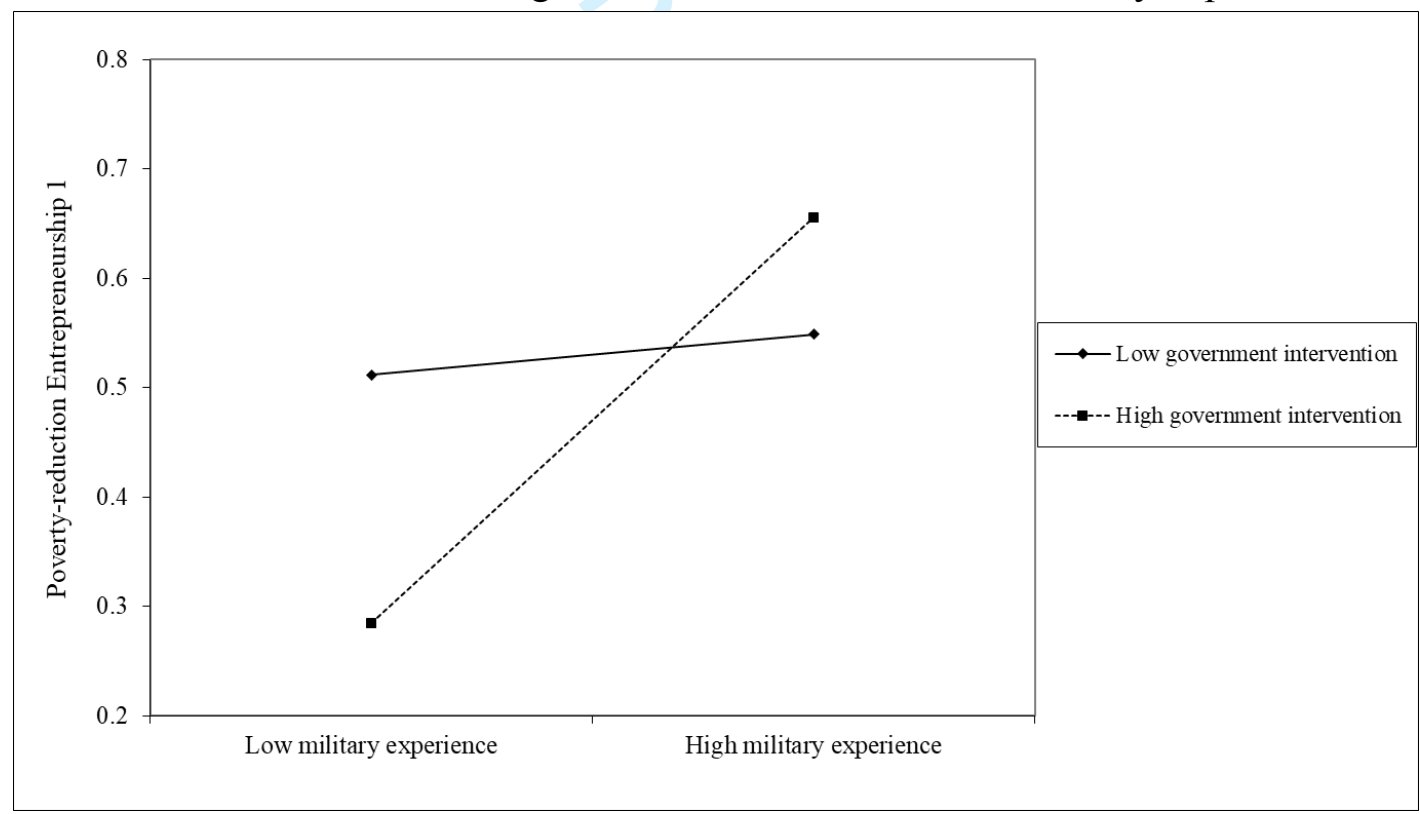

49 
Figure 4

Robustness result 1:

Interaction effect between corporate philanthropy 1 and military experience

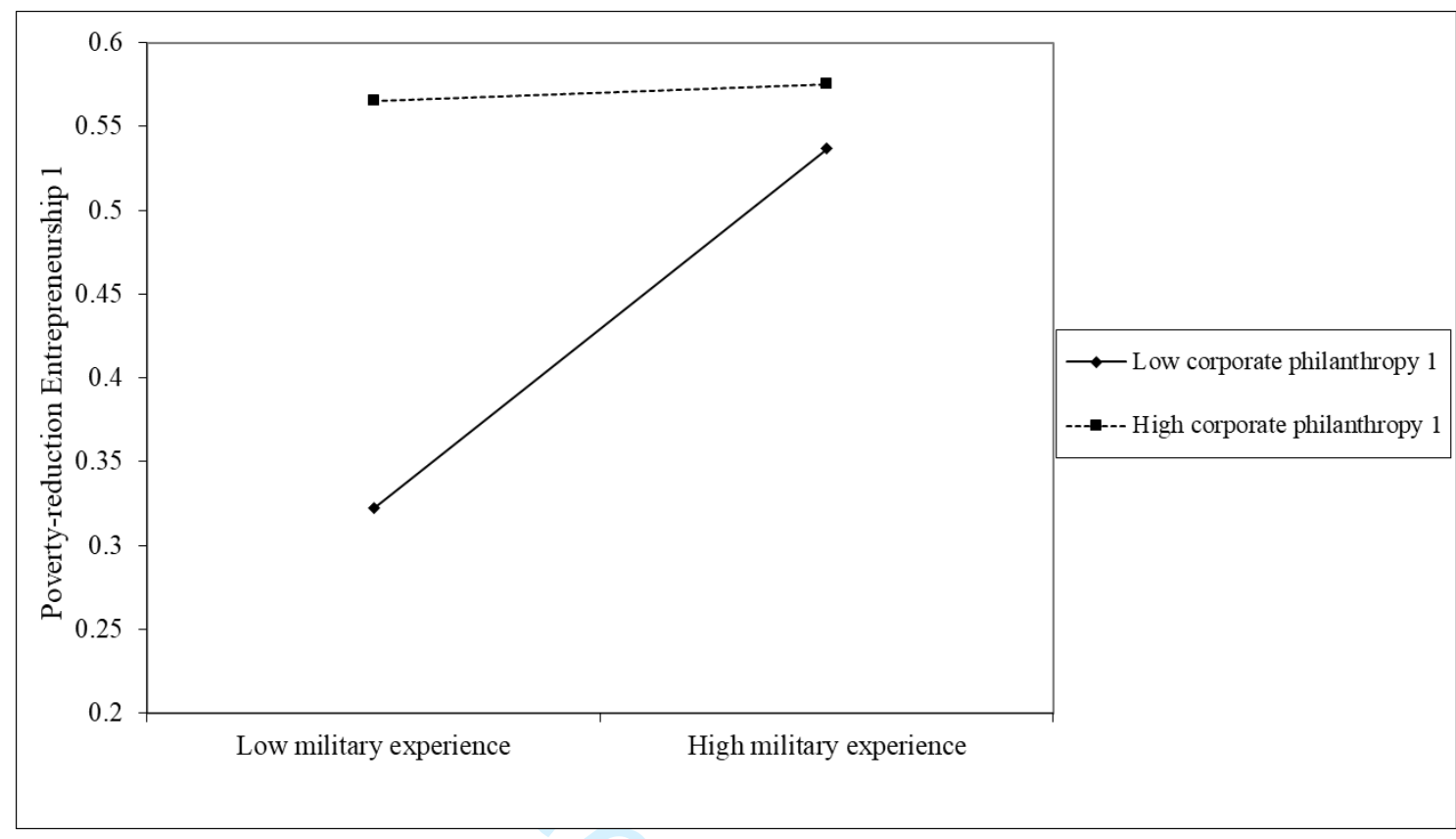

Figure 5

Robustness result 1:

Interaction effect between government intervention and military experience

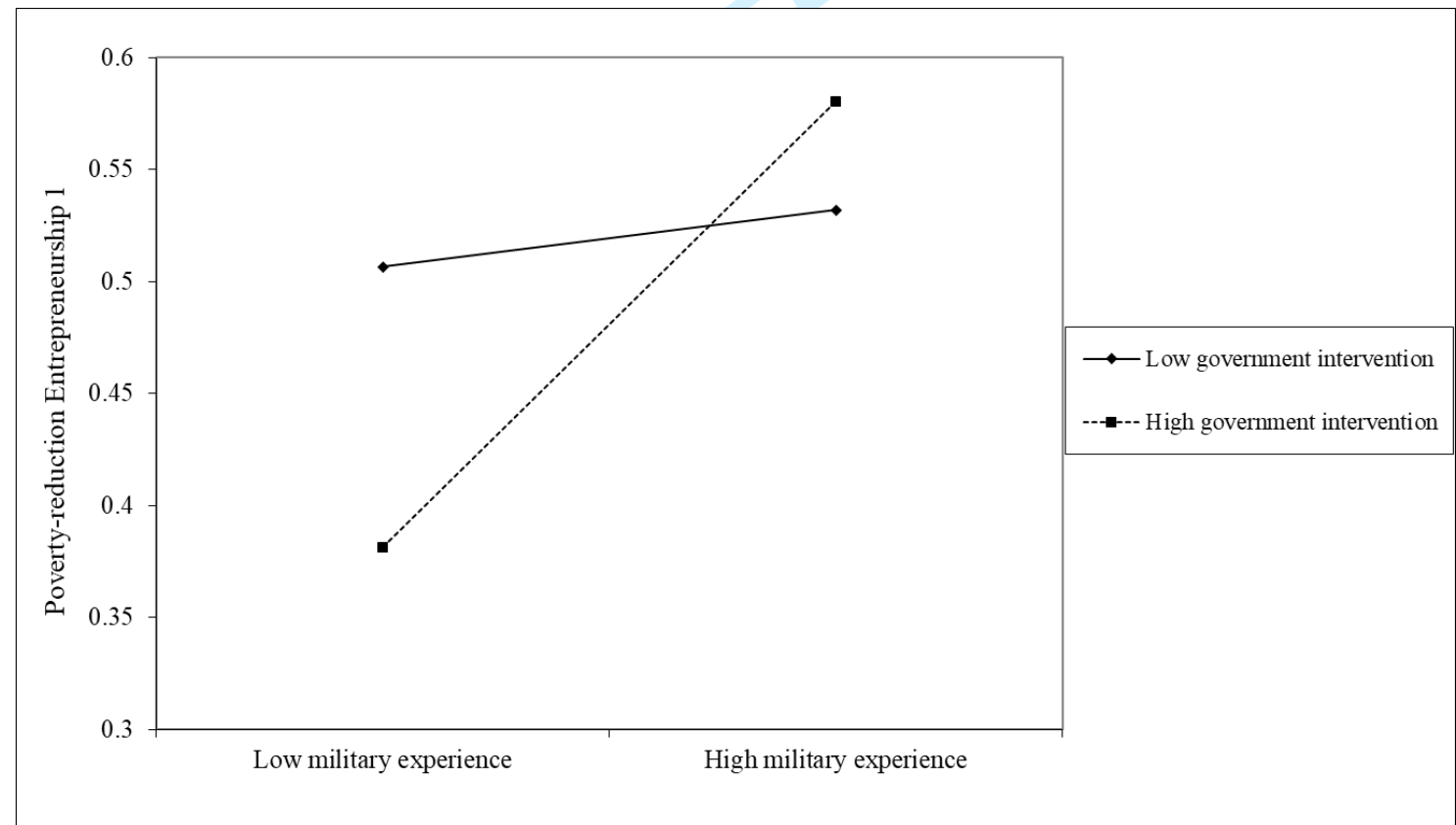


Figure 6

Robustness result 2:

Interaction effect between corporate philanthropy 1 and military experience

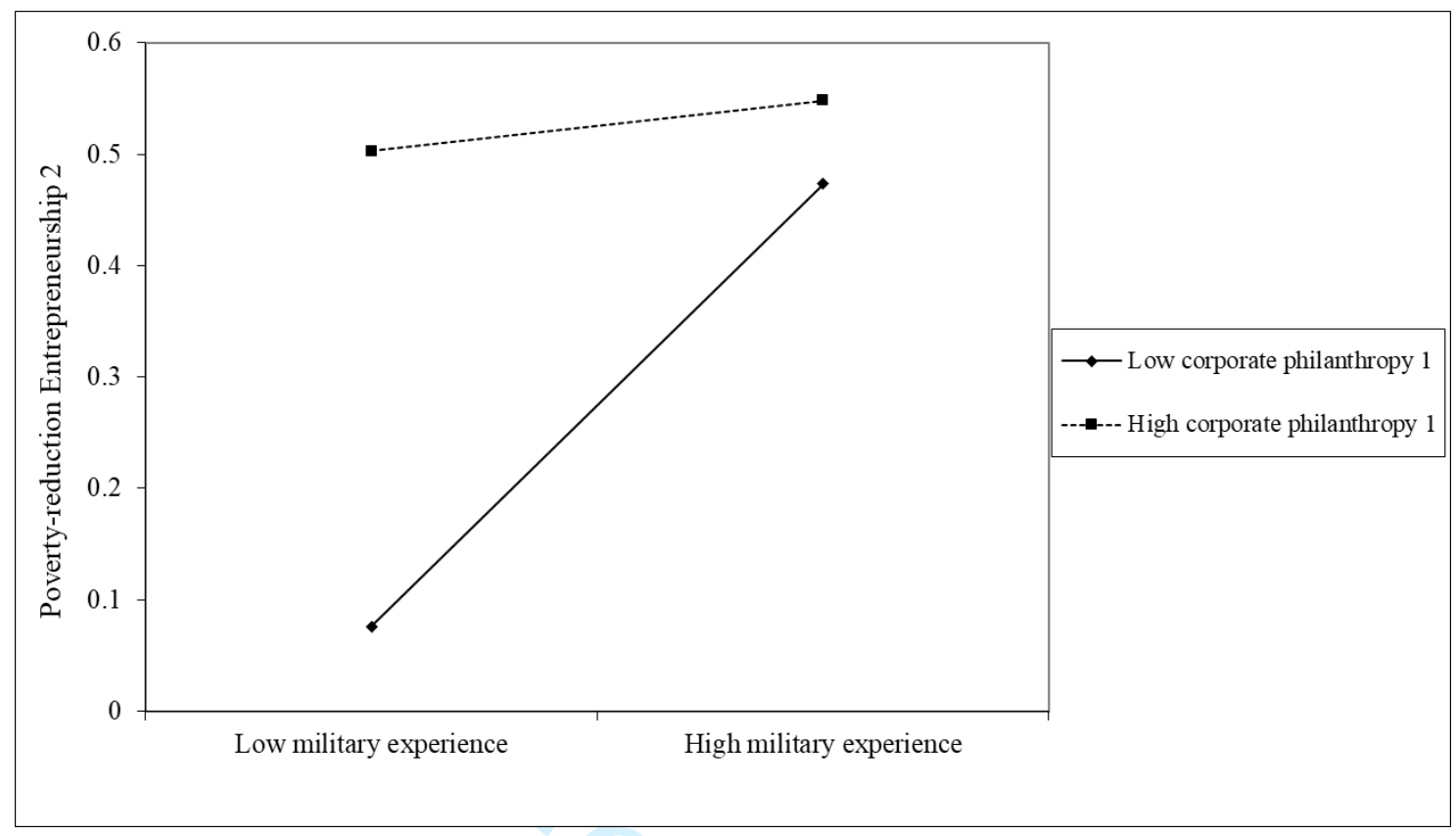

Figure 7

Robustness result 2:

Interaction effect between government intervention and military experience

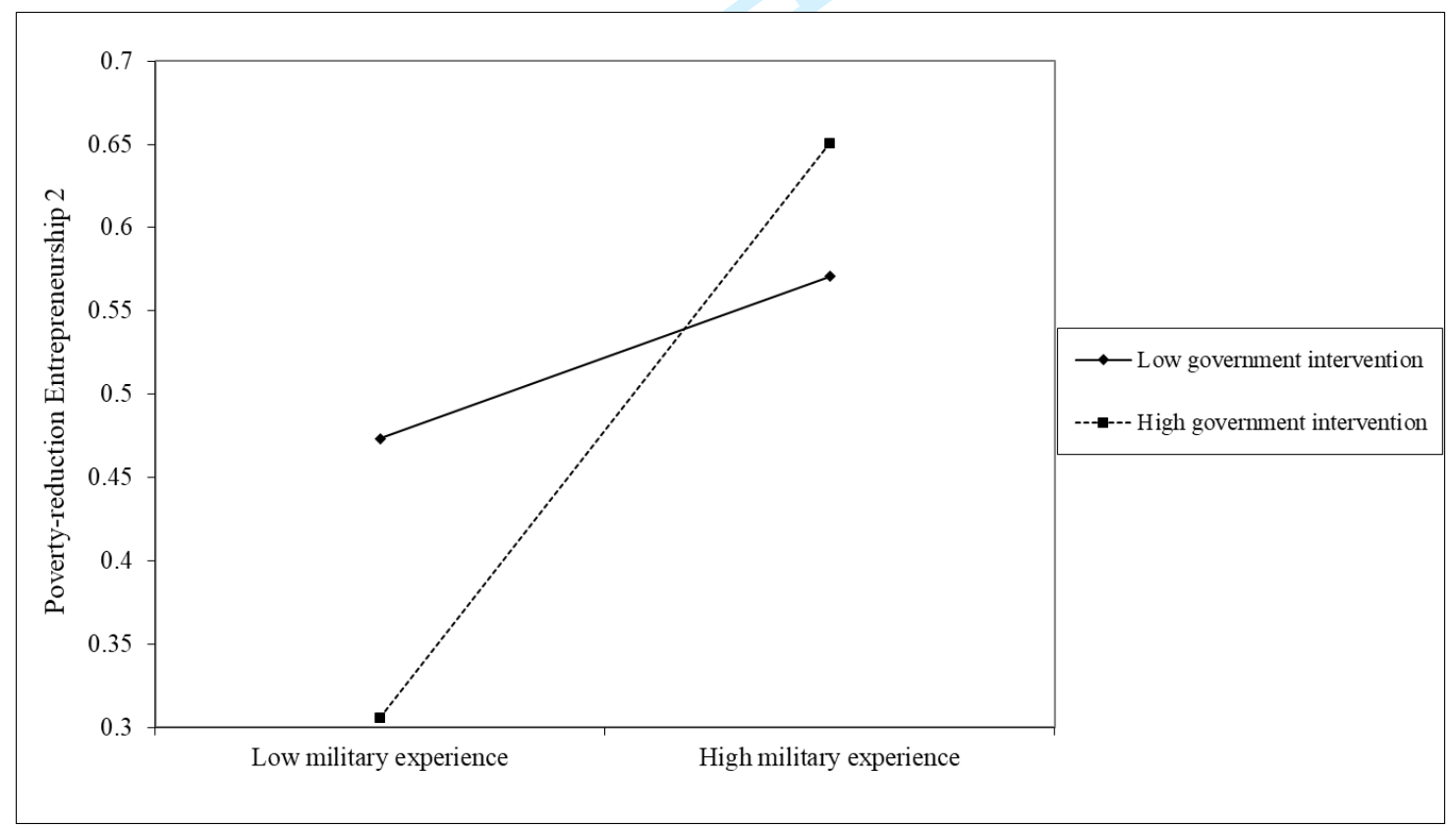


Figure 8

Robustness result 3:

Interaction effect between corporate philanthropy 2 and military experience

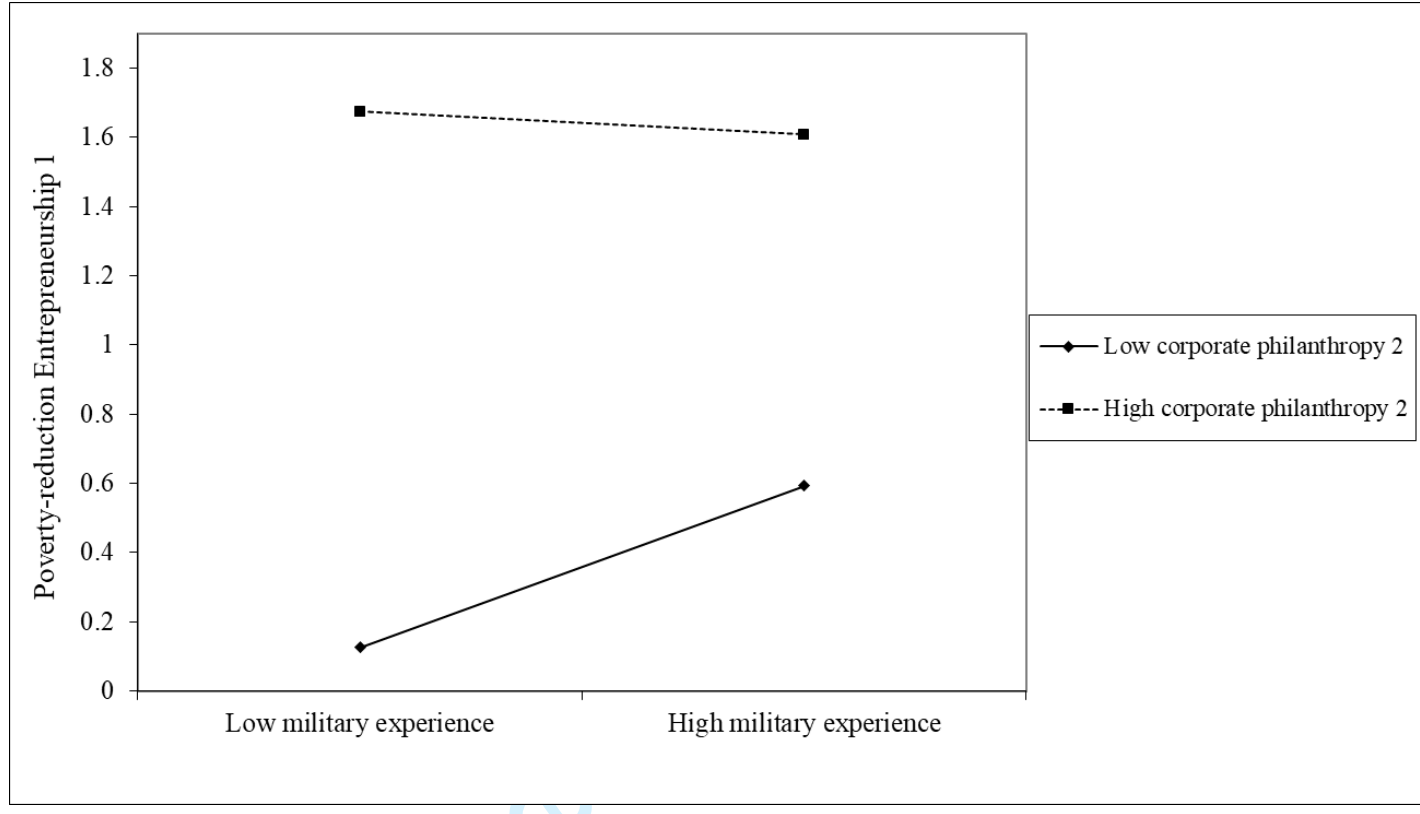

